\title{
Crustal Architecture at the Collision Zone Between Rivera and North American Plates at the Jalisco Block: Tsujal Project
}

\author{
Juanjo Dañobeitia, ${ }^{1}$ Rafael Bartolomé, ${ }^{2}$ Manel Prada, ${ }^{2,6}$ Francisco Nuñez-Cornú, ${ }^{3}$ Diego Córdoba, ${ }^{4}$ \\ William L. Bandy, ${ }^{5}$ F. Estrada, ${ }^{2}$ Alejandra L. Cameselle, ${ }^{2}$ Diana Nuñez, ${ }^{3,4}$ Arturo Castellón, ${ }^{1}$ \\ José Luis Alonso, ${ }^{1}$ Carlos Mortera, ${ }^{5}$ and Modesto Ortiz ${ }^{7}$
}

\begin{abstract}
Processing and analysis of new multichannel seismic records, coincident with wide-angle seismic profiles, acquired in the framework of the TsuJal project allow us to investigate in detail the complex structure of the oceanic domain in the collision zone between Rivera Plate and Block Jalisco at its northern termination. The subducting Rivera Plate, which is overridden by the North American Plate-Jalisco Block, is clearly identified up to $21.5^{\circ} \mathrm{N}$ (just south of Maria Magdalena Island) as a two clear reflections that we interpret as the interplate and Moho discontinuities. North of the Tres Marias Islands the seismic images display a different tectonic scenario with structures that are consistent with large faulting and rifted margin. A two-dimensional velocity approach for the crustal geometry is achieved using joint refraction/reflection travel time tomography, the uncertainty of the results is assessed by means of Monte Carlo analysis. Our results show an average oceanic crustal thickness of 6-7 km with a moderate increase towards the Jalisco Block, an anomalous thick layers $(\sim 3.0 \mathrm{~km})$ displaying a relatively low velocity $(\sim 5.5 \mathrm{~km} / \mathrm{s})$ underneath Maria Magdalena Rise, and an estimated Moho depth deeper than $15 \mathrm{~km}$ in the collision zone between Rivera Plate and Jalisco Block. We have also determined an anomalous crust on the western flank of the Tres Marias Islands, which may be related to the initial phases of continental breakup of the Baja California Peninsula and Mexico mainland. High-resolution bathymetry provides remarkable images of intensive slope instabilities marked by relatively large slides scars of more than $40 \mathrm{~km}^{2}$ extent, and mass-wasting deposits probably triggered by the intense seismicity in the area.
\end{abstract}

1 Unidad de Tecnología Marina, CSIC, P. Marítimo de la Barceloneta 37-49, 08003 Barcelona, Spain. E-mail: jjdanobeitia@utm.csic.es

2 Instituto de Ciencias del Mar, CSIC, P. Marítimo de la Barceloneta 37-49, 08003 Barcelona, Spain.

3 Centro Universitario de la Costa (CUC), Av. Universidad 203, Del. Ixtapa, 48280 Puerto Vallarta, Mexico.

4 Universidad Complutense de Madrid, Ciudad Universitaria, Plaza Ciencias, s/n, 28040 Madrid, Spain.

5 Instituto de Geofísica, UNAM, Ciudad Universitaria, Delegación Coyoacán, C.P. 04510, Mexico, D.F., Mexico.

6 Present Address: Dublin Institute for Advanced Studies, Dublin, Ireland.

7 Centro de Investigacion Cientifica y de Educacion Superior de Ensenada, Mexico, Mexico.

\section{Introduction}

The crustal architecture of the western boundary of Mexico is strongly controlled by the Middle America Trench (MAT) which is the morphological expression of an active subduction zone involving the North American Plate overriding the relatively young Rivera and Cocos plates, and it is the location of significant tectonics, widespread seismicity and magmatism (Fig. 1). Both oceanic plates, Rivera and Cocos, are fragments of the Farallon Plate (e.g., Atwater and Stock 1998); the Rivera Plate acting independently since $10 \mathrm{Ma}$ (DeMets and Traylen 2000). The Rivera Plate is a key structural element to understand the complex geodynamic interactions that take place at the west coast of Mexico (Yang et al. 2009); with accreting seafloor along its western boundary, the Pacific Rivera Rise (PRR), and subducting seafloor at the northern tip of the MAT along the Jalisco Block. Several authors have shown that the Rivera Plate is kinematically distinct from the North American and Cocos plates (e.g., Bandy and Yan 1989; DeMets and Stein 1990). Moreover, the eastern termination of the Rivera-Cocos boundary is still uncertain since no bathymetric expressions can be clearly associated with the plate boundary (Bourgois and Michaud 1991; Bandy et al. 1995; Michaud et al. 2001; Peláez Gaviria et al. 2013). The lithosphere of the Rivera Plate, dated as late Miocene near the MAT (Klitgord and Mammerickx 1982), is consumed at the trench at a convergence rate that varies from $5.0 \mathrm{~cm} /$ year near the Rivera Cocos Plate Boundary to $2.0-3.0 \mathrm{~cm} /$ year along the Tres Marias Escarpment (Kostoglodov and Bandy 1995). 


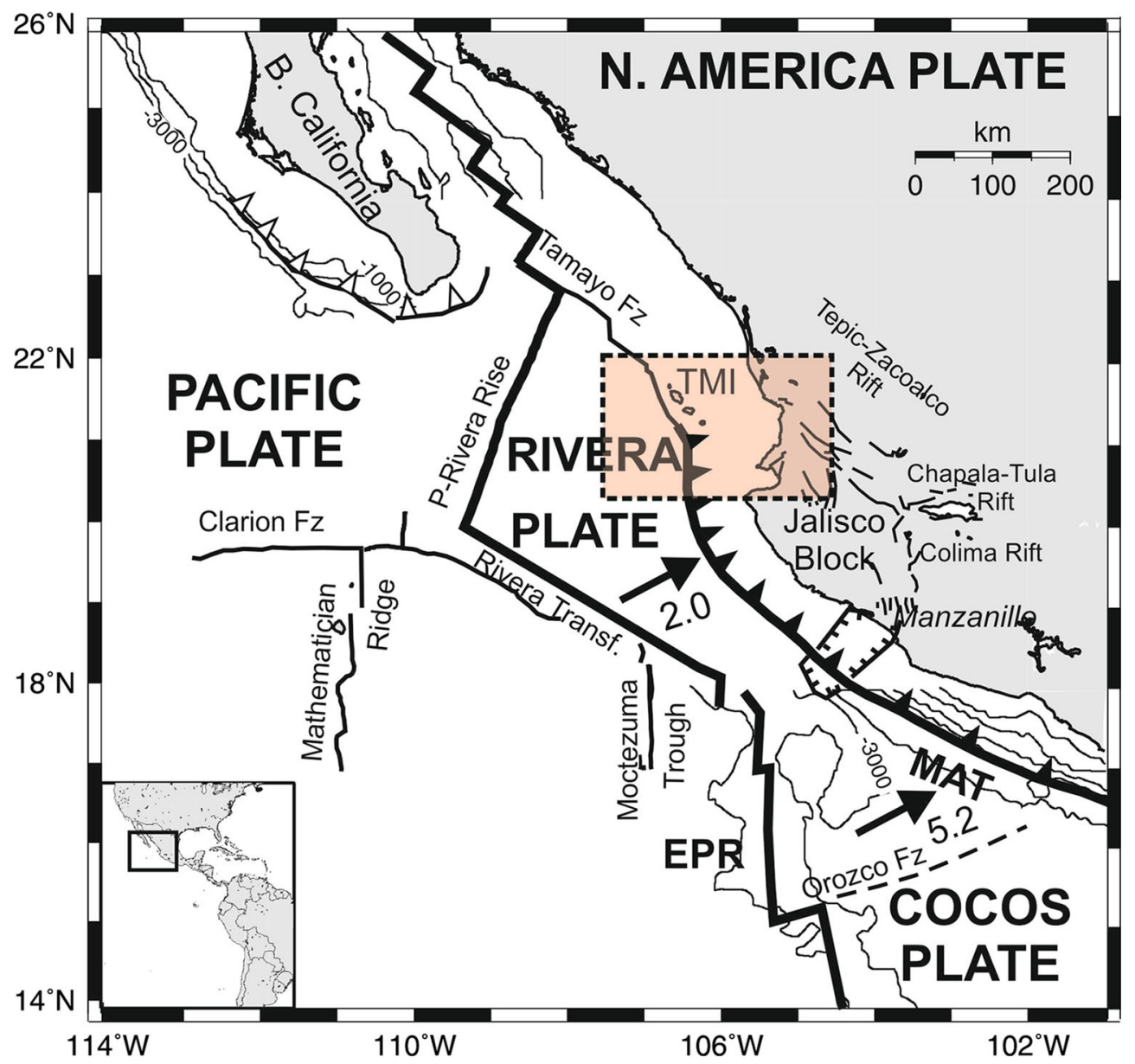

Figure 1

Tectonic framework map showing the main structural features in the interaction area of the Rivera, Pacific, North America and Cocos plates. Pink frame shows the study area around the Tres Marias Islands (TMI). MAT Middle America Trench, EPR East Pacific Rise

The studies of the internal structure of the subducted plate have relied primarily on potential field data (Bandy et al. 1993, 1999), and only few seismic profiles are reported in the literature (Bourgois et al. 1988; Bourgois and Michaud 1991; Khutorskoy et al. 1994; Michaud et al. 1996; Bandy et al. 2005). In 1996 the Spanish R/V Hespérides and the Mexican R/V́s Altair and Humboldt surveyed the northwestern Mexican margin between $16^{\circ} \mathrm{N}$ and $30^{\circ} \mathrm{N}$ in a geophysical experiment named Crustal Offshore Research Transect by Extensive Seismic Profiling, CORTES-P96 (Dañobeitia et al. 1997). During this research expedition swath bathymetry, backscattering and multichannel seismic reflection data and wideangle profiles were acquired. These data (Bartolome et al. 2011) show a strong reflection, at $2 \mathrm{~s}$ (twtt) underneath the sedimentary cover, interpreted as the Moho discontinuity and they computed a mean dip angle of $7^{\circ} \pm 1^{\circ}$ for the initial subduction of the Rivera Plate, the dip angle gently increases towards the south. The angle of subduction of the Rivera Plate has been obtained from studies of local seismicity and crustal structure, and displays a gentle subduction angle near the trench (Nuñez-Cornú et al. 2002, 2016), then dives more steeply into the mantle at an angle of $34^{\circ}$ (Gutierrez et al. 2015). The Cocos Plate has a slightly curved subducted slab with oblique geometry dipping to the Colima Rift, ranging in dip from $18^{\circ}$ in the south to $30^{\circ}$ in the north $(\mathrm{Gu}-$ tierrez et al. 2015). This has led to the proposal of a step in the slab between the Cocos and Rivera Plates at the present time (Nixon 1982; Ferrari et al. 2001) 
formed during a period of very low convergence rate (19 mm/year on average) between 8.5 and $4.6 \mathrm{Ma}$ (DeMets and Traylen 2000).

The seismicity is discontinuous and moderate in magnitude (Nuñez-Cornú et al. 2002; Núñez-Cornú et al. 2004) (Fig. 2), although some of the largest destructive earthquakes in western America are reported offshore of the Jalisco region (Singh et al. 1985; Courboulex et al. 1997). The largest instrumental record occurring in Mexico is the 1932 Jalisco $M_{\mathrm{w}}=8.2$ event (e.g., Eissler and McNally 1984; Singh et al. 1985; Okal and Borrero 2011). The main event of the 1995 earthquake was a subduction-related thrust earthquake that activated normal faults along the northwest margin of Manzanillo $\left(19^{\circ} \mathrm{N}\right.$, $105^{\circ} \mathrm{W}$, Fig. 2), clearly indicating present day plate convergence. Most of the shocks during the 1932 strike occurred at the Rivera-North America boundary, while the shocks/aftershocks of 1995 seem to happen at the rupture zone between Rivera-Cocos Plate interface (Pacheco et al.1997, Núñez-Cornú 2011).
During the spring of 2014, within the framework of TSUJAL project (Núñez-Cornú et al. 2016), Spanish and Mexican scientists investigated the western margin of Mexico at the collision zone between the Rivera, Cocos and North American plates. The main objective was to define the crustal architecture of this active margin and recognize potential structural sources that can trigger earthquakes and tsunamis at the RiveraNorth America convergence zone. To achieve these goals a wide range of geophysical data were acquired aboard the RRS James Cook. Herein we present the northernmost post-stack time migrated multichannel seismic (MCS) sections together with coincident wideangle (WA) seismic data (Fig. 3). These new data show seismic images from the Earth's surface down to the Moho that enables to seismically characterize the crustal structure of the overriding and subducting plates in the offshore area of the Jalisco Block. We also describe the spatial distribution of the incoming plates (sediment, crust and uppermost mantle lithosphere) and identify some of the geodynamic processes occurring in this area.

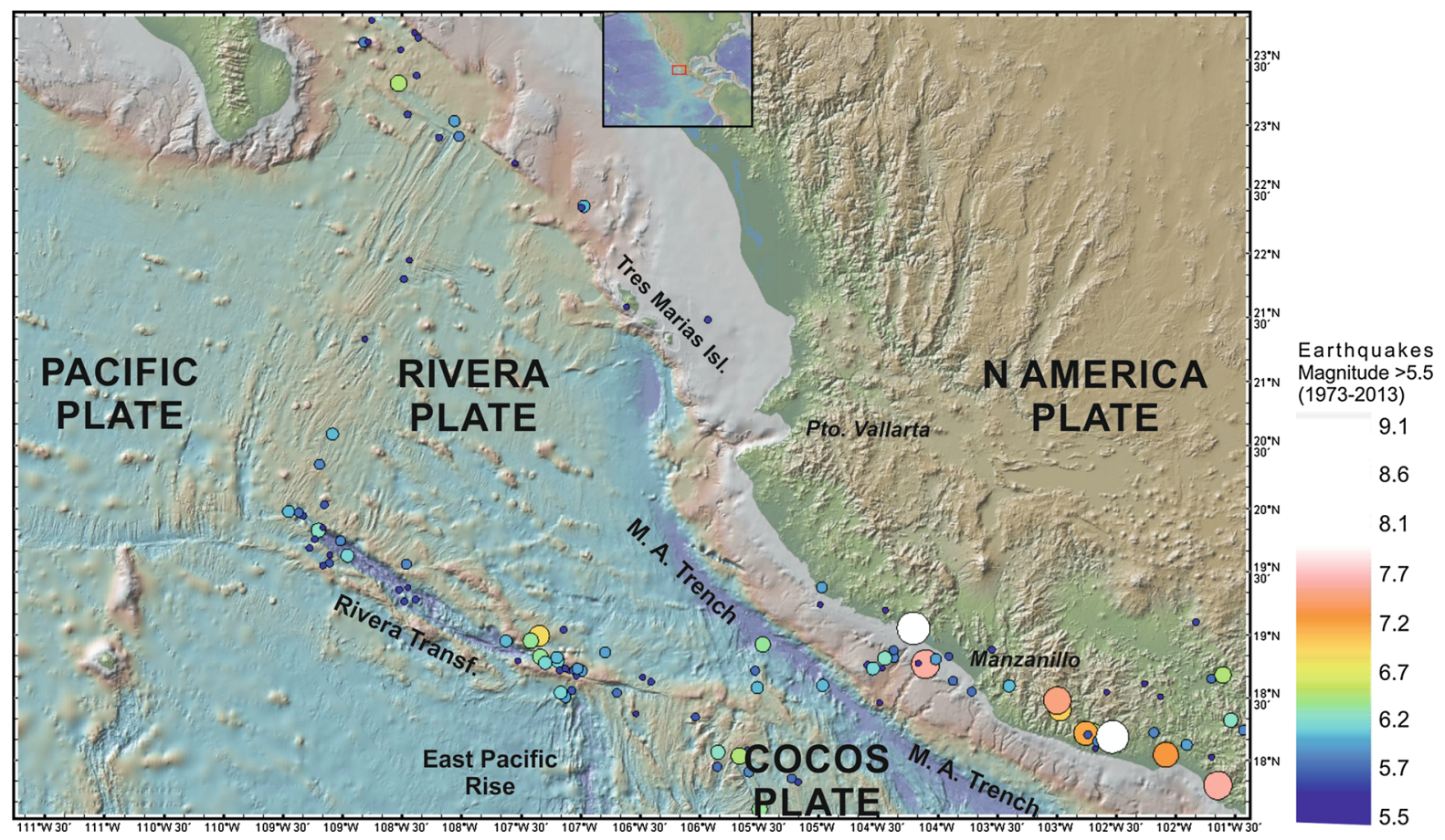

Figure 2

Seismicity from 1973 to 2013 for magnitude $>5.5$. Note the location of earthquakes with $M_{\mathrm{w}}$ larger than 7.0 along the Middle American Trench 


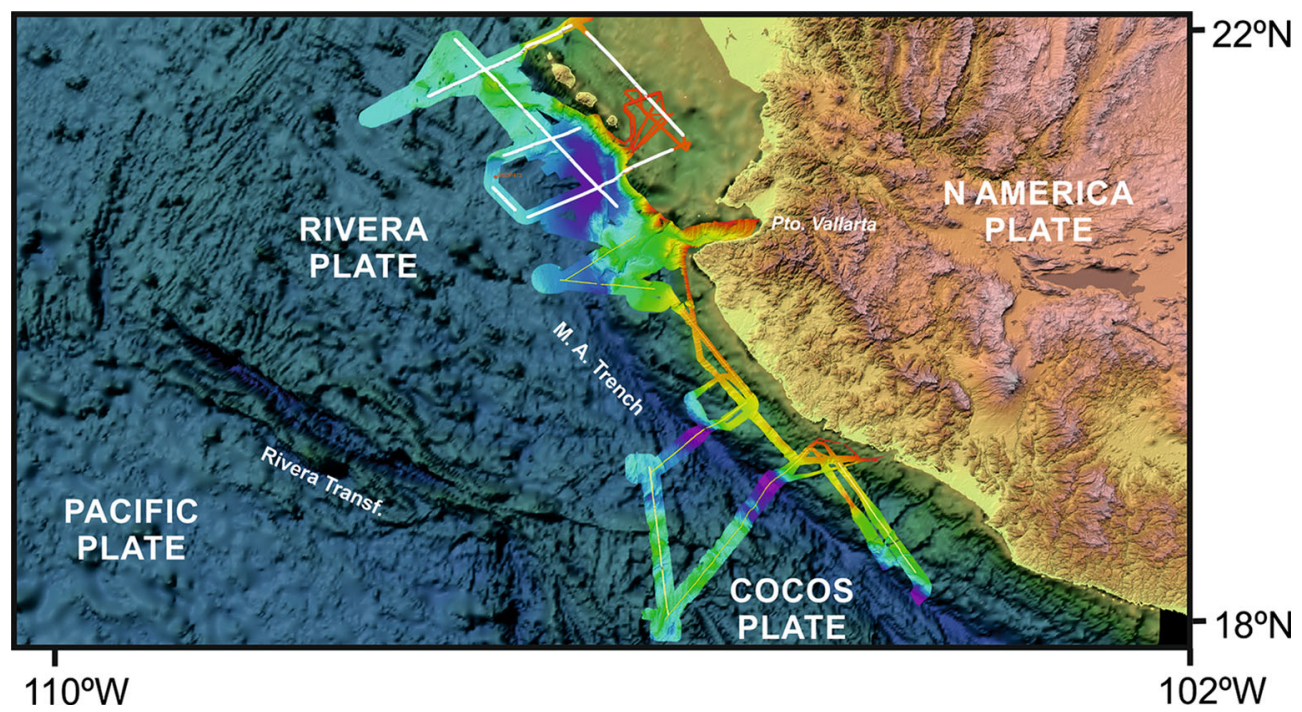

Figure 3

Track-chart and bathymetry acquired during the TsJual Survey along the seismic lines. White lines denote the seismic lines analyzed and interpreted in the northern Rivera Plate-Jalisco Block study of this paper

\section{Geological Setting}

The western margin of Mexico is an active tectonic region displaying ongoing, strong, tectonic plate interactions: spreading process in the East Pacific Rise (EPR) in the West boundary of the Rivera Plate (Mammerickx 1984) at an average halfspreading rate of $2.7 \mathrm{~cm} /$ year. Subduction of the Rivera and Cocos plates beneath the North American Plate (NA) in the Middle American Trench (MAT) occur on its eastern boundary. The trench extends from the Tres Marias Islands, located south of the Gulf of California at $21^{\circ} \mathrm{N}$, southward along the Mexican coast for a distance of approximately $3000 \mathrm{~km}$, with the distance between the trench axis and the shoreline of only 40-60 km. The boundary between Rivera and Cocos plates and the SE boundary between the three plates (Rivera, Cocos and NA has been classically defined as diffuse, although recent works based on Bouger anomaly gravity models (Alvarez and Yutsis 2015) located the boundary at a line from the MAT to the region of the Colima Volcanic complex. We can find in the SE boundary other processes, such as ridge-trench collisions between the East Pacific Rise (EPR) and the MAT, off Manzanillo, and slab windowing between the Rivera and Cocos plates (Bandy 1992), which is characterized by lithospheric extension and delineated by the El Gordo graben.

The Rivera Plate fragmented from the Cocos Plate at $10 \mathrm{Ma}$ (DeMets and Traylen 2000). Its convergence rate with respect to the North American Plate is moderate, about 2-3 cm/year, although this value and the degree of obliquity (see discussion by Kostoglodov and Bandy 1995) are still debated. This rate is always slower than the adjacent Cocos Plate (5-8 cm/year). Rivera Plate subduction is characterized by a steeper angle and more northerly trajectory than the adjacent Cocos Plate, with a dip angle increasing at depths around $100 \mathrm{~km}$. A summary of DSDP site 473 results and interpretations of a $287 \mathrm{~m}$ length core on the Rivera Plate, south of Tres Marias Islands, indicates that older sediments are 6-6.5 m.y. (Upper Miocene) and no older than 8 m.y. with igneous rocks at the end of the core. Moreover, Klitgord and Mammerickx (1982) published that the lithosphere of the Rivera Plate consumed at the trench dates as late as Miocene (approx. 9 Ma), whereas the Cocos crust near the Rivera Plate is $10 \mathrm{Ma}$ and progressively becomes older to the SE, being $25 \mathrm{Ma}$ old at $90^{\circ} \mathrm{W}$ (Pardo and Suárez 1995; Mammerickx and Kiltgord 1982). Terrigenous 
clay deposited in the early Pliocene to Quaternary and calcareous claystone deposited during early Pliocene are separated by a strong seismic reflector from the Upper Miocene sediments in the core. Sediments are unexpectedly terrigenous despite the distance from land and the MAT. Sediment accumulation rates are $40 \mathrm{~m} / \mathrm{m}$.y. for the last 3 million years and $20 \mathrm{~m} / \mathrm{m}$.y. from 3 to 6.5 million years. Sediment velocities are $1.5-1.6 \mathrm{~km} / \mathrm{s}$ increasing to $1.98 \mathrm{~km} / \mathrm{s}$ at the basal sediments. Igneous rocks below the sediments are mainly massive, altered diabase with a density of $2.7 \mathrm{~g} / \mathrm{cm}^{3}$ and a velocity of $5.2-5.3 \mathrm{~km} / \mathrm{s}$, but a fragment of pillow basalt was found at the bottom of the hole.

The margin along the Middle America trench from the Tres Marias Islands to the Manzanillo Area $\left(18^{\circ} \mathrm{N}\right.$, $\left.104^{\circ} \mathrm{W}\right)$, was uplifted and emergent before the late Miocene. The margin started to subside during the upper Miocene-lower Pliocene at least until the Pliocene-Quaternary limit (Mercier de Lépinay et al. 1997). From the Pliocene-Quaternary limit (approx. $2.5 \mathrm{Ma}$ ), the Manzanillo area continue subsiding whereas the Tres Marias Islands began to be uplifted (McCloy et al. 1988). Regional subsidence of an active margin is generally related to tectonic erosion and therefore, such long-term subduction-erosion regimen for the Manzanillo area implies trench retreat along the margin (Mercier de Lépinay et al. 1997). The recent overview of Ramirez-Herrera et al. (2011) confirm that, although spatial and temporal variability exists, coastal subsidence is occurring at the southern Colima Graben and the Guerrero seismic gap near Acapulco, whereas coastal uplift is occurring between Puerto Vallarta and Manzanillo and along the coast south of the Colima/El Gordo Graben until Lazaro Cardenas, South Acapulco.

The Jalisco Block is generally considered as part of the NA Plate may have some degree of independent motion. There are active faults along the TepicChapala, Colima and Chapala rifts in southwestern Mexico that some authors considered related to Jalisco-North America tectonics (Allan 1986; Johnson and Harrison 1989; Allan et al. 1991; Fig. 1). Selvans et al. (2011) find also a slow motion of $2 \mathrm{~mm} /$ year to the southwest of the stations in the Jalisco Block relative to the NA Plate in a recent GPS campaign near the triple junction, which is compatible with such a tearing; however, motion could be related to the earthquake cycle behavior of subduction megathrusts and, therefore, the Jalisco Block might not have an independent motion.

Recent studies also evidence gas hydrates in the western (Minshull et al. 2005; Bartolome et al. 2011, 2016; Bandy and Mortera 2012) in the form of bottom simulating reflectors (BSR) on multichannel seismic reflection profile located on the continental slope area of the northern part of the Jalisco Subduction Zone, off Puerto Vallarta, between $20^{\circ}$ and $20.5^{\circ} \mathrm{N}$, and in the south off Manzanillo. Thus, there is evidence to suggest that the Pacific margin of Mexico may contain significant reserves of hydrocarbons in the form of gas hydrates.

\section{TSUJAL Project}

The global objective of the TSUJAL project included the characterization of the shallow and deep structure of the Rivera Plate and the Jalisco Block in order to investigate the recent tectonic deformation due to the subduction process affecting the area, and the extensional zones associated with transform faults (Núñez-Cornú et al. 2016). In addition, the data places constraints on the geophysical parameters related to the lithospheric structure in the western Mexican margin (Fig. 1). The integration of these parameters together with the available acquired geological information will allow us to obtain a complete image of the lithosphere that will be used for a seismic and tsunamigenic hazard assessment (Trejo-Gómez et al. 2015).

The specific objectives of TSUJAL survey include characterizing the subduction of the Rivera Plate along the western Mexican margin, clarifying the convergence direction and angle of subduction, in the oceanic crust, the trench, the continental slope and rise and up to the coast. In addition, to identify the active structures, mainly faults, with recent neotectonic deformations that are prone for generating earthquakes and tsunamis. There has been a substantial effort in the project to image the shallow geometry, pattern and style of deformation of the morphological structures using high-resolution methods, and the correlation with its seafloor topography. Finally, we plan to identify and typify mass 
transport deposits and submarine landslides associate to active faults, emphasizing the ones that can generate earthquakes and tsunamis. TSUJAL data were acquired (Bartolome et al. 2015) in the framework of a bi-lateral barter agreement between the National Environmental Research Council (NERC) and Consejo Superior de Investigaciones Cientificas (CSIC), under the European research alliance OFEG (Ocean Facility Exchange Group).

\section{Methods}

In this section, we outline the acquisition, processing and modeling of seismic and bathymetric data used in this work.

\subsection{Multichannel Seismic Reflection Data}

The TSUJAL survey focused on the acquisition of Multichannel Seismic Reflection (MCS) data using a 5.85-km-long digital streamer of the Unidad de Tecnología Marina (UTM-CSIC, Spain) and the airgun source system from the RRS James Cook (NERC, UK), which includes 12 Bolt $^{\circledR}$ G-Guns 1500LL with 4 air compressors and a laboratory equipped to control the firing and synchronization of guns (Fig. 4). A big source array was designed to maximize the energy concentrated at the lowest frequency range. The shooting interval was defined at $50 \mathrm{~m}$, as a compromise between maximum redundancy of data (CMP fold) and capacity of the air compressors (Table 1). During the entire marine seismic survey we applied the Precautionary Principle following the guide recommendations of Joint Nature Conservation Committee. Thus, the safety distance was determined to be $1000 \mathrm{~m}$ from the guns and only on a couple of occasions marine mammals and turtles were sighted causing the acquisition operations to be stopped.

A total of $14 \mathrm{MCS}$ profiles were acquired between $108^{\circ}$ and $104^{\circ} \mathrm{W}$ and $17.5^{\circ}$ and $22^{\circ} \mathrm{N}$. Herein we present the northern MCS network of profiles acquired around the Tres Marias Islands, at the NW of Bahia Banderas (Fig. 5a), which amounts to a total of seven MCS profiles of about $620 \mathrm{~km}$ length (Table 2).

\subsection{Refraction and Wide-Angle Seismic Data}

The TSUJAL experiment used 16 short period Ocean Bottom Seismometers OBS model LC2000SP (1 hydrophone and three components seismometer) designed and built by the Scripps Oceanographic Institution (La Jolla, USA) and provided by the Marine Technology Unit (UTM-CSIC). We used a source that consisted of 14 air guns, in a six array configuration, with a total volume of 6800 cubic inches, towed at $15 \mathrm{~m}$ depth, shooting every $120 \mathrm{~s}$ along each line. A network of 6 wide-angle (WA) profiles was recorded, in the region around the Maria Islands, by 16 OBSs at 32 locations, in Jalisco and Nayarit offshore regions, as well as on a terrestrial network (100 portable seismic stations) in 240 locations across 5 seismic profiles of $200-300 \mathrm{~km}$ in length combined with the Seismological Network of the State of Jalisco (RESAJ, Núñez-Cornú et al. 2016). Figure $5 b$ shows the location of these lines and the location of the OBSs along each line. In this work, we present offshore WAS data of lines RTSIM01 $(95 \mathrm{~km})$ and RTS-IM02 $(225 \mathrm{~km})$. WAS data along transect RTS-IM01 were acquired by 4 OBSs, whereas 6 OBSs were used to record data along line RTS-IM02. The average receiver spacing between OBS was $\sim 20 \mathrm{~km}$. Processing of WAS data involved a band pass filter $(3-7 ; 20-25 \mathrm{~Hz})$, and a deconvolution and a wiener shaping filter (prediction lag of $60 \mathrm{~ms}$ ) in order to retrieve far-offset signal. After the processing we were able to identify arrival times up to $100-120 \mathrm{~km}$ offset.

In Figs. 6 and 7, we display the records sections, together with the seismic phases identified and consequent ray tracing used along both lines RTSIM01 and RTS-IM02 with a reduction velocity of $8 \mathrm{~km} / \mathrm{s}$. The phases used for the modeling correspond to $\mathrm{P}$-waves refracted through the overriding plate $(\mathrm{Pgc})$, oceanic crust (Pgo) (which is clearly identified as a first arrival until $40 \mathrm{~km}$ offset) and mantle (Pn) (first arrival are observed at far offsets until more than $100 \mathrm{~km}$ ), and near offset reflections at the intraplate boundary (PiP), and the higher amplitude reflection at the Moho $(\mathrm{PmP})$ some of which are observed at a relatively near offset range $(\sim 30 \mathrm{~km})$. Overall, a total of $\sim 1600$ and 3800 travel times were manually selected from receiver gathers of lines 


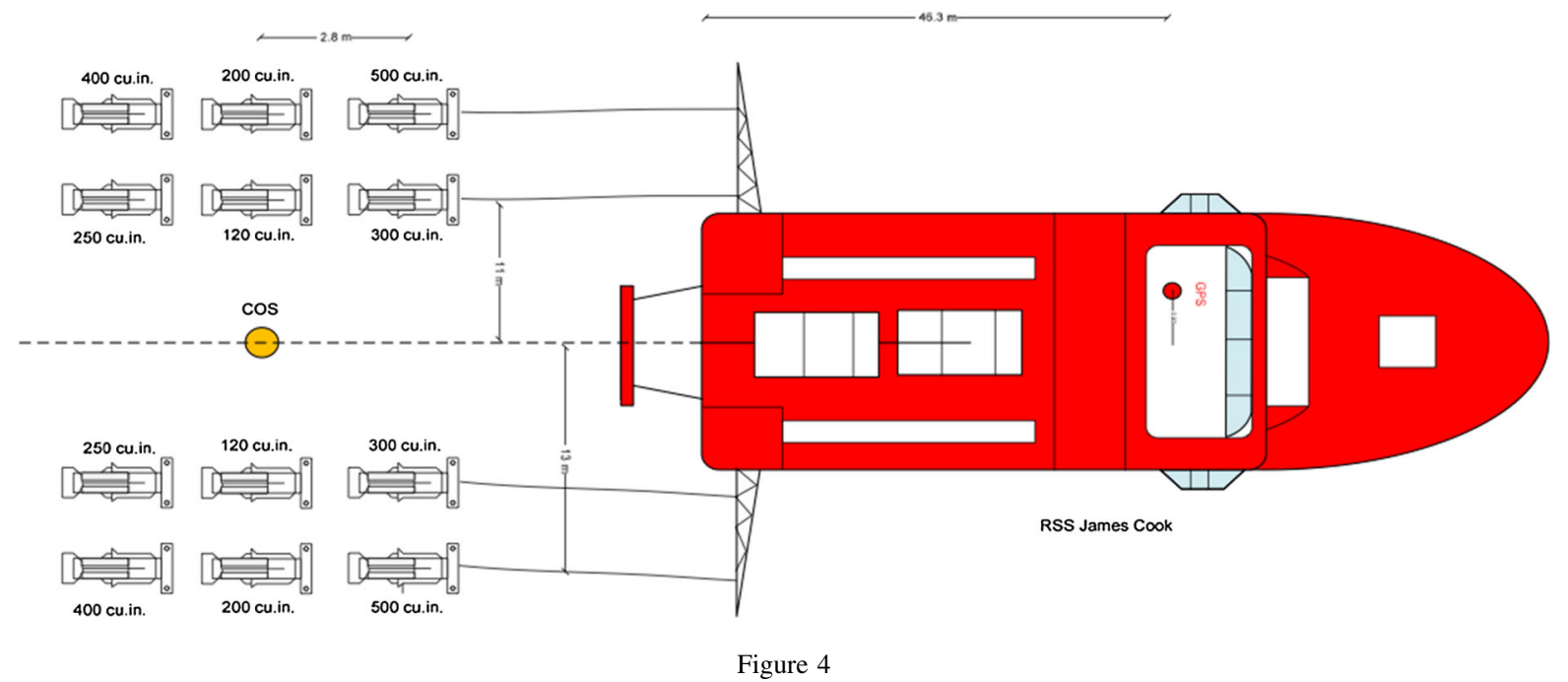

Total gun-array (3540 cu.in.) configuration used during acquisition of MCS profiles TS08 to TS14

Table 1

Source parameters used during TsuJal northern seismic survey, including multichannel (TS08-TS14) and wide-angle (WA) profiles used in this study

Source parameters

\begin{tabular}{ll}
\hline Source controller & Big Shot ${ }^{\circledR}$ \\
Source type & Bolt ${ }^{\circledR}$ G.Guns 1500LL \\
Air pressure & $2000 \mathrm{psi}$ \\
Volume & $3540 \mathrm{cu}$. in. (TS08-TS14) \\
Compressors & $6800 \mathrm{cu}$ in. (WA) \\
& $4 \times$ Hamworthy ${ }^{\mathrm{TM}} 565 \mathrm{~W} 100$ \\
Number of arrays & 4 \\
Total number of guns & $12(3$ guns for array) \\
Gun synchronization & $\pm 0.1 \mathrm{~ms}$ \\
Deployment depth & $8 \mathrm{~m}$ \\
Shot interval & $50 \mathrm{~m}$ for mcs \\
& $120 \mathrm{~s}$ for wa \\
Aiming point & $50 \mathrm{~ms}$ \\
\hline
\end{tabular}

RTS-IM01 and RTS-IM02, respectively. For these picked travel times, errors are supposed to be half a period of the dominant frequency of the recorded signal, thus, that we use an uncertainty of $50 \mathrm{~ms}$ for the travel time of crustal refracted phases $(\mathrm{Pg})$, and for longer offset; of $60-80 \mathrm{~ms}$ for mantle refractions $(\mathrm{Pn})$, and of 90-100 ms for intraplate and Moho reflections (PiP and $\mathrm{PmP}$ ). The uncertainty is chosen on the basis of the signal-to-noise ratio, which correlated with the offset (i.e., the signal-to-noise ratio decreases with offset).
The selected travel times were then inverted using the joint refraction-reflection travel-time tomography method published in Korenaga et al. (2000). This method uses a set of velocity and depth smoothing constraints defined by correlation lengths (CL) to stabilize the iterative inversion. After several tests, we used velocity CL that varies between $3 \mathrm{~km}$ at the top of the model to $15 \mathrm{~km}$ at the bottom for horizontal CL, and between 0.5 and $5 \mathrm{~km}$ for vertical CL. Depth CL was set at $5 \mathrm{~km}$.

To obtain the final models (Fig. 8), we have followed a layer stripping strategy, which is commonly used in crustal tomography approaches as it allows to retrieve the geometry of the main geological interfaces in detail (e.g., intraplate and Moho; Sallarès et al. 2013a). This strategy consists of inverting seismic phases sequentially from near to far offset. The number of steps depends on the number reflections (i.e., layers) interpreted along each profile. This way, inversion of line RTS-IM02 has consisted of three steps: first we inverted both overriding crust first arrivals (Pgc) and reflections at the intraplate boundary (PiP), second we inverted Pgc together with oceanic crust first arrivals (Pgo) and Moho reflections (PmP), and finally, in the third and last step we inverted all the previous refractions together with Moho reflections and mantle refractions (i.e., Pgc, Pgo, Pn and PmP). The final root mean 

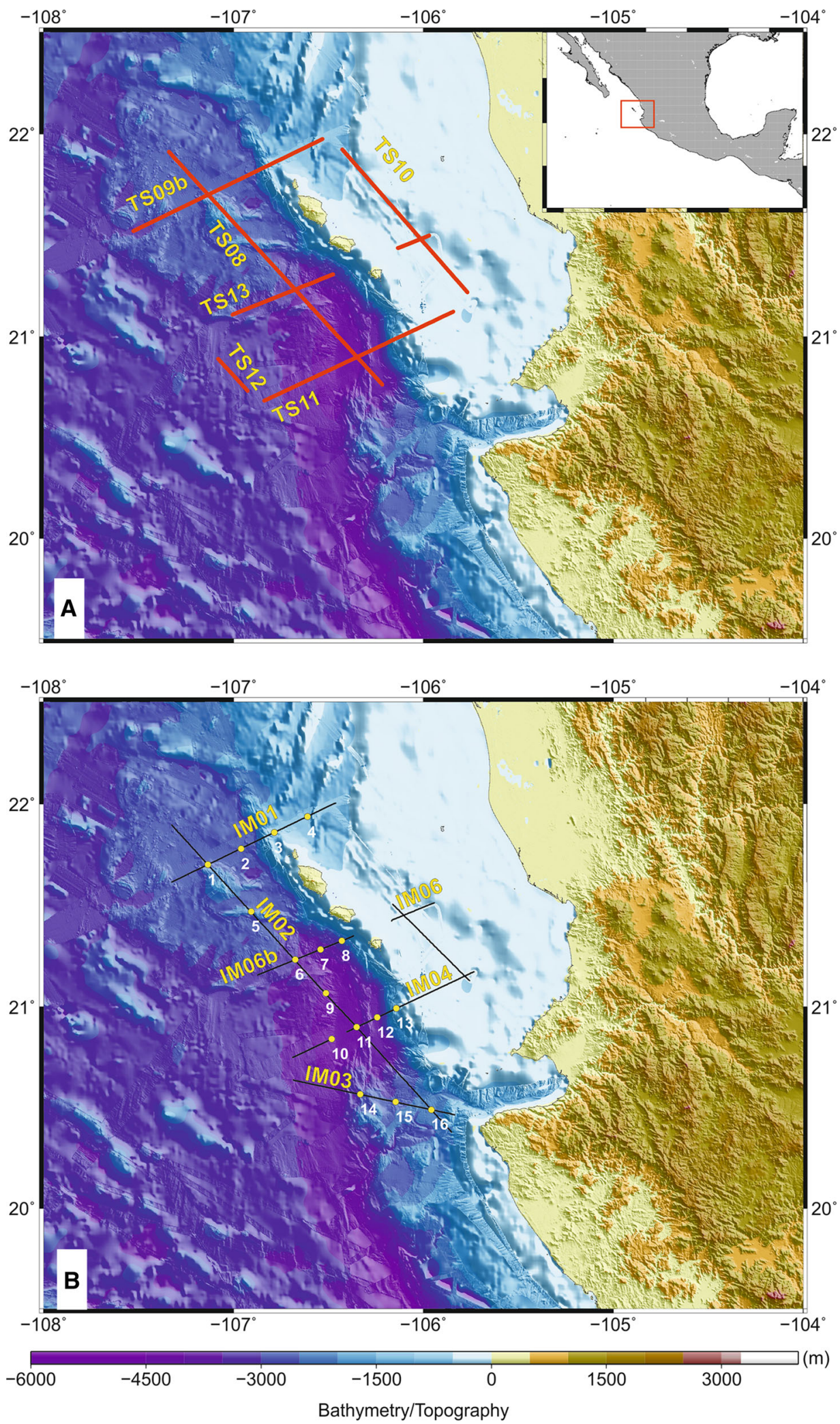
Figure 5

Location map of the Seismic Profiling around Tres Marias Islands acquired during TsuJal survey. a Displays the position and names of MCS profiles. b Displays the position of the wide-angle profiles, coincident with MCS location. White numbering indicates OBS locations in each profile

Table 2

MCS profile locations and length during TsuJal northern survey

Profile Latitude Longitude Latitude Longitude Length
$\begin{array}{llll}\left({ }^{\circ}\right) \mathrm{N} & \left({ }^{\circ}\right) \mathrm{W} & \left({ }^{\circ}\right) \mathrm{N} & \left({ }^{\circ}\right) \mathrm{WE}\end{array}$

Start of line End of line

\begin{tabular}{llllll}
\hline TS08 & 20,76 & 106,22 & 21,91 & 107,34 & 172,75 \\
TS09b & 21,52 & 107,52 & 21,98 & 106,53 & 115,25 \\
TS010 & 21,92 & 106,43 & 21,22 & 105,77 & 103,9 \\
TS11 & 21,12 & 105,84 & 20,68 & 106,84 & 115,1 \\
TS12 & 20,73 & 106,93 & 20,89 & 107,08 & 24,05 \\
TS13 & 21,11 & 107,01 & 21,31 & 106,47 & 59,55 \\
TS14 & 21,44 & 106,14 & 21,50 & 105,97 & 18,55 \\
\hline
\end{tabular}

square values for model RTS-IM01 and RTS-IM02 are $\sim 45$ and $\sim 50 \mathrm{~ms}$, respectively.

\subsubsection{Model Parameter Uncertainty}

The uncertainty of the model parameters (Vp, depth) in crust for both profiles (RTS-IM01 and RTS-IM02) has been evaluated by means of a Monte Carlo analysis following a similar approach as Korenaga et al. (2000). A total of 200 Monte Carlo different tests were used in this approach.

Initial Vp models were built following a twolayered structure. The upper layer velocity gradient was set by velocities of $1.5 \mathrm{~km} / \mathrm{s}$ at the top (seafloor) to $5 \mathrm{~km} / \mathrm{s}$ at its bottom, whereas the lower layer gradient was defined by velocities between $5.5 \mathrm{~km} / \mathrm{s}$ at the top to $7 \mathrm{~km} / \mathrm{s}$ at the bottom. The upper layer thickness was randomly chosen between values of 1 $\mathrm{km}$ to $3 \mathrm{~km}$, while a range of $8 \mathrm{~km}$ and $12 \mathrm{~km}$ was set to choose the thickness of the lower layer. Upper and lower velocities of each layer were randomly varied within $10 \%$. The initial set of 200 flat Moho reflectors were randomly set at depths between $13 \mathrm{~km}$ and $17 \mathrm{~km}$. Overall, the initial $\mathrm{Vp}$ uncertainty was set at $0.3 \mathrm{~km} / \mathrm{s}$, while the depth uncertainty was $\sim 2 \mathrm{~km}$. The set of 200 perturbed data set were created by randomly modifying the selected travel time within their uncertainties, that is $50 \mathrm{~ms}$ for $\mathrm{Pg}$ and $90 \mathrm{~ms}$ for PmP. Additionally, velocity and depth
CL were also randomly chosen, similar to Korenaga and Sager (2012), varying between $3 \mathrm{~km}$ and $15 \mathrm{~km}$, from top to bottom for CL horizontal, and between $0.5 \mathrm{~km}$ and $5 \mathrm{~km}$ for CL vertical (op. cit.)

According to Tarantola (1987), the velocity and depth standard deviation of the number of successfully inverted models can be taken as a measure of the model parameter uncertainty. The results of inverting 200 Monte Carlo realizations are shown in Fig. 9 for both models. The derivative weight sum (DWS) is also included in Fig. 9, which gives accurateness on the linear sensitivity of the inversion (Toomey and Foulger 1989).

The crustal Vp uncertainty for both lines RTSIM01 and RTS-IM02 varies between $0.1 \mathrm{~km} / \mathrm{s}$ and $0.2 \mathrm{~km} / \mathrm{s}$, being $<0.1 \mathrm{~km} / \mathrm{s}$ in areas with high ray density (Fig. 9). A high uncertainty exists (up to $0.5 \mathrm{~km} / \mathrm{s}$ ) in the first $2-3 \mathrm{~km}$ of the model. This is commonly observed in regions with high vertical $\mathrm{Vp}$ gradients like the crust-mantle or the sedimentsbasement boundary (Sallarès et al. 2013b). The depth uncertainty for the Moho reflector has uncertainties between 0.8 and $0.5 \mathrm{~km}$ along Line RTS-IM01, and $0.2-1.25 \mathrm{~km}$ along Line RTS-IM02. The overall crustal velocity structure and depth of the Moho along both models is significantly well resolved despite of the high receiver spacing $(\sim 20 \mathrm{~km})$.

\subsection{Swath-Bathymetry Acquisition and Processing}

During the TSUJAL (JC-098) cruise high-resolution swath-bathymetry and backscatter data were acquired with two Kongsberg Simrad's multibeam echosounder, hull-mounted in the RSS James Cook: EM120 and EM710. The EM120 was running during the whole cruise and the EM710 only in shallow waters $(<500 \mathrm{~m})$. The nominal sonar frequency for the EM120 is $12 \mathrm{kHz}$ with an angular coverage sector of up to 150 degrees and 191 beams per ping as narrow as 1 degree. Achievable swath width on a flat bottom will normally be up to 5.5 times the water depth. The EM710 operates at sonar frequencies in the $70-100 \mathrm{kHz}$ range with an angular coverage sector of up to $140^{\circ}$ and 128 beams. Both echosounders were operated simultaneously with a hydrographic echosounders Simrad EA600. To avoid interferences all echosounders were triggered by a 
A
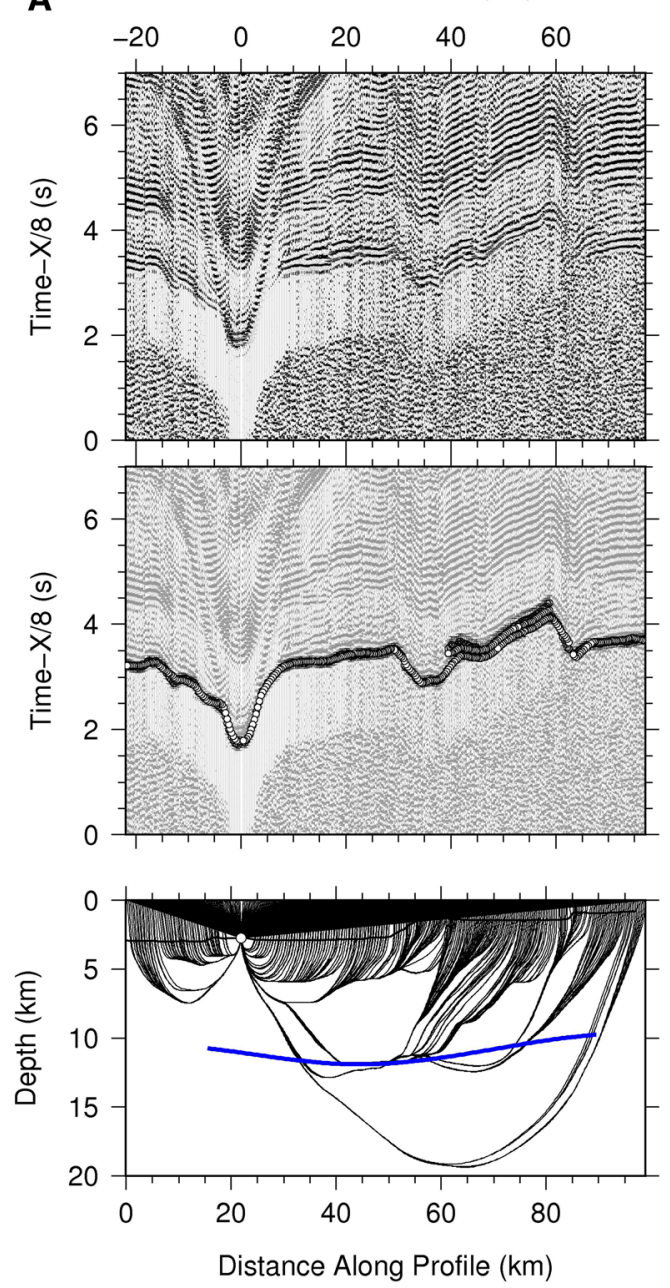

B
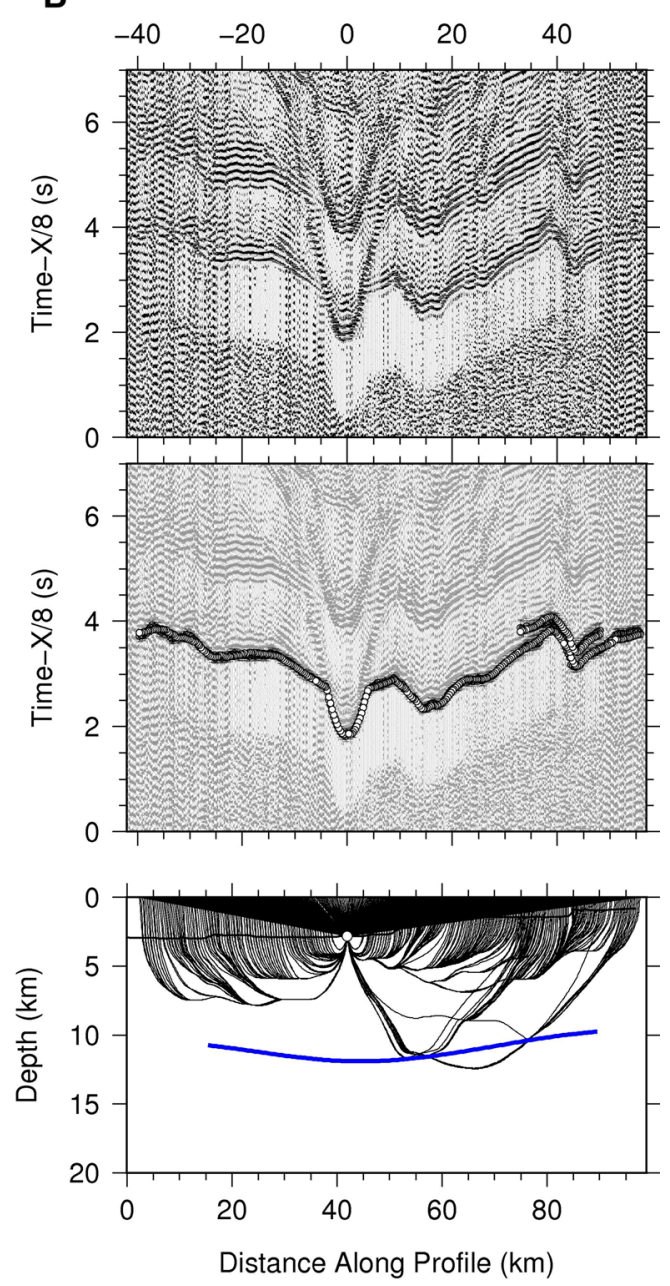

Figure 6

Record sections (up), identified phases (middle) and ray tracing (bottom) corresponding to the four OBSs deployed along the wide-angle seismic profile TS-IM01, north of TMI. Blue line indicates the location of the crust-mantle boundary (Moho reflector)

Kongsberg K-Sync V1.7.0 synchronization unit. We calibrated the sound velocity in the water column every day by performing XBT probes.

Due of the characteristics of this cruise, most of the lines were covered up to four times, including: during the deployment of OBS; while shooting refraction line; during recovery of OBS and finally while firing for the MCS seismic reflection data acquisition. This has conditioned the strategy of the multibeam acquisition data and data density, which can reach up to more than 2000 values $/ \mathrm{km}^{2}$ in lines, sailed up to five times or when shallow bathymetric profiles were recorded with two echosounders simultaneously.

All bathymetric data recorded has been processed on board using CARIS (Hips \& Sips v. 8.1). Processing steps include navigation editor for ping removal corresponding to the stop time during deployment and recovering of OBS sensors and filtering of sections acquired at speeds lower than 2 knots. Soundings were also filtered with the "Swath Editor" command to remove the most obvious bad or/ 

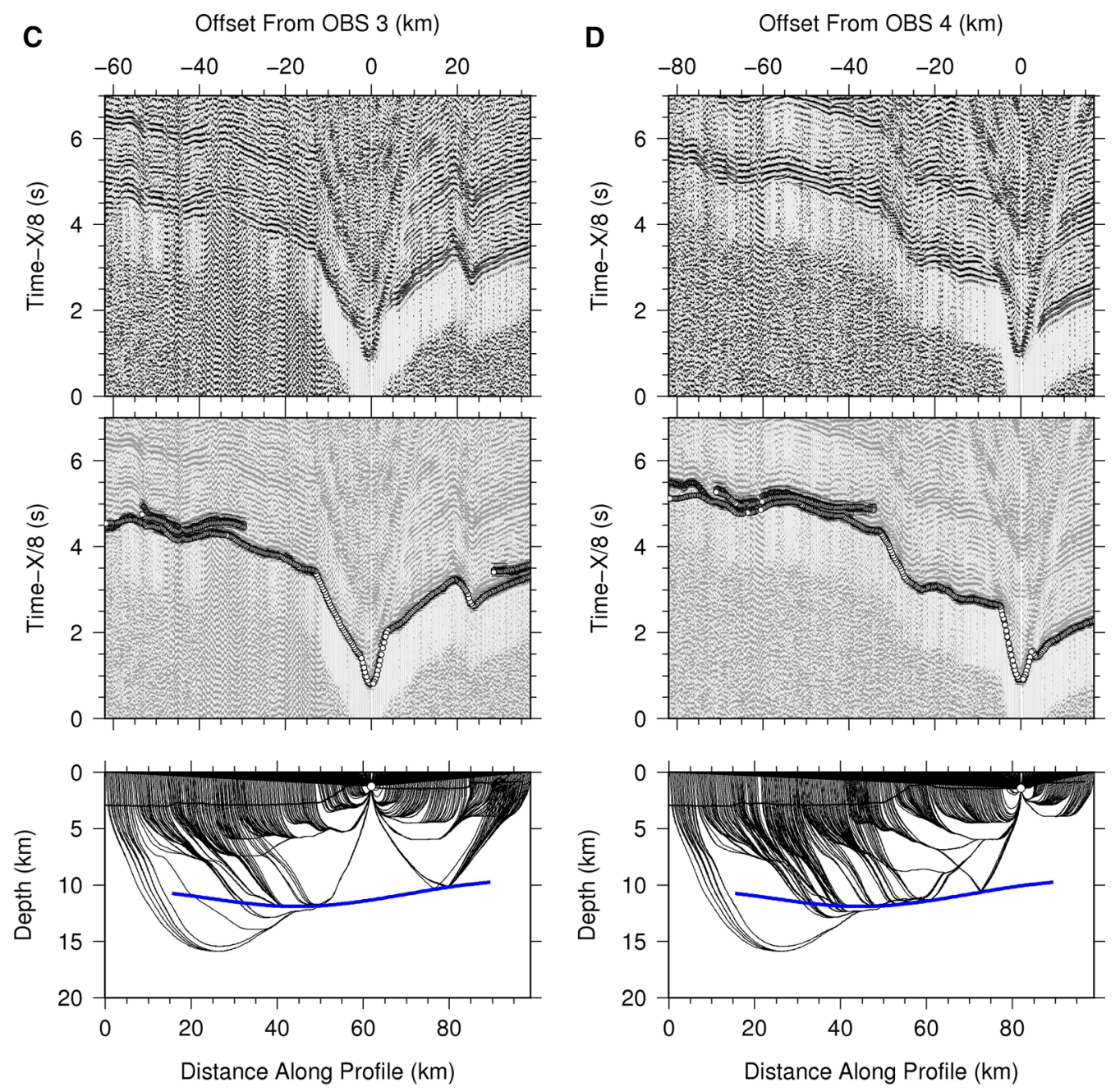

Figure 6 continued

and isolated sounds. Then, the whole base surface is systematically inspected and cleaned with the " $2 \mathrm{D}$ Subset editor" command.

\section{Oceanic Crustal Structure}

\subsection{Significance of the MCS, Refraction and Wide- Angle Data}

The northernmost MCS profile, TS09b (Fig. 5a), strikes SW-NE for $120 \mathrm{~km}$. It is located about $30 \mathrm{~km}$ north of the Tres Marias Islands (TMI) at the eastern flank of the Tres Marias escarpment (TME). In the migrated section of profile TS09b (Fig. 10) there is a basin up (between marks $95-110 \mathrm{~km}$ ) to $15 \mathrm{~km}$ wide, infilled by up to $1 \mathrm{~s}$ (twtt) of sediments, which runs parallel to the TME. From its location and shape, this basin appears to be formed by a half graben, the main fault located to the NE. This basin may have been developed coincident with the collision of the Rivera Plate as a pull-apart basin or by block rotation in an oblique subduction system, that is compatible with the structural transform regime during the last 5.5 my, and basically overlaps the older extensional tectonics (Moore and Curray 1982). Some compressional structures are observed near the eastern flank of the TME. In the western flank of TME we observe some faults that could be related to the faulting and 

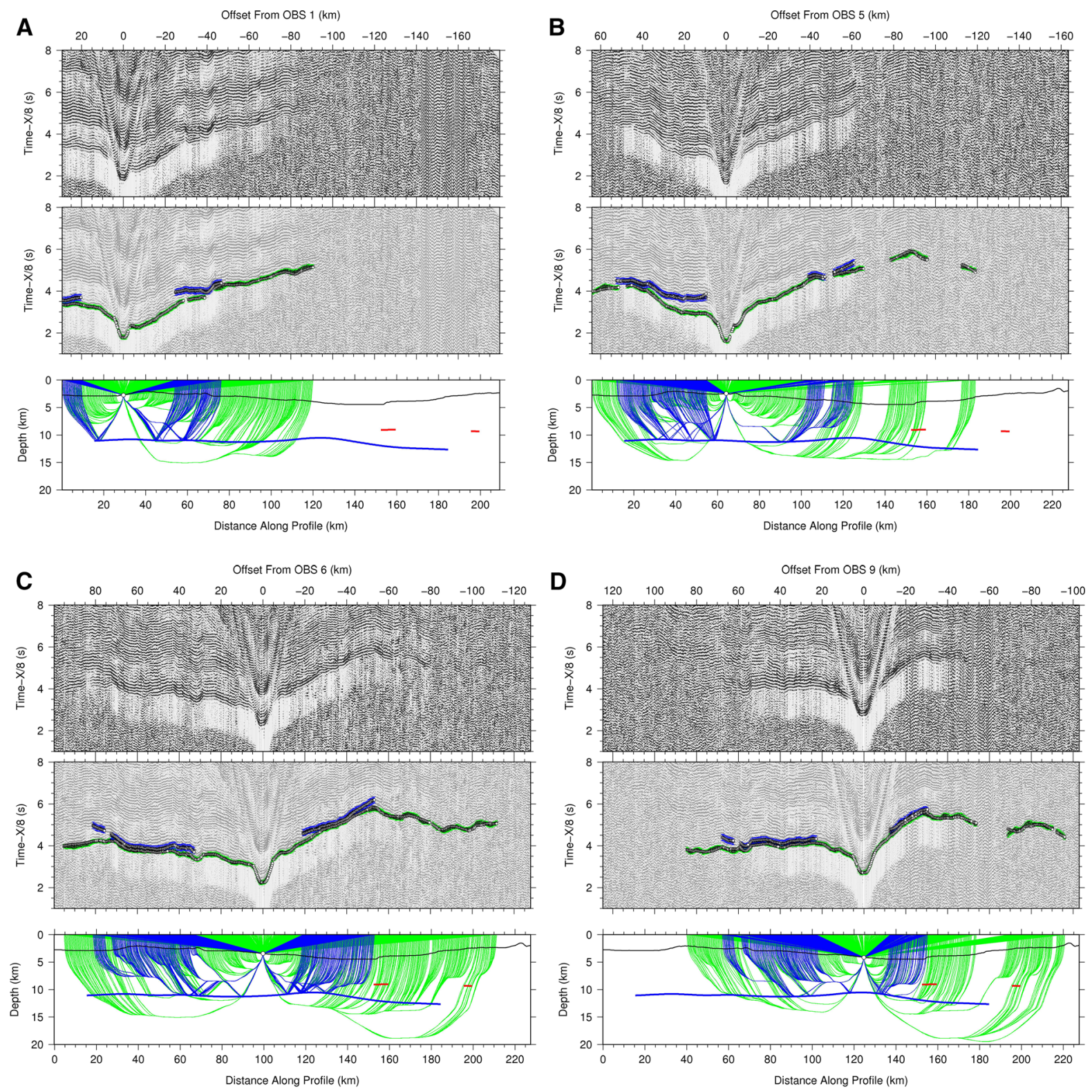

Figure 7

Record sections (up), identified phases (middle) and ray tracing (bottom) corresponding to the six OBSs deployed along the wide-angle profile RTS-IM02, west of TMI

rifting processes in the early stages of initial axis along the Maria Magdalena Rise (MMR), this is reinforced by NNE trending magnetic anomalies, which record the early opening between the southern tip of Baja California peninsula and western Mexico (Lonsdale 1991).

In this initial extensional period extensive rifting of the continental crust occurred at the tip of the
Peninsula and in the conjugate Tres Marias Block. Then, rifting aborted leaving remnants of continental fragments, dyke injection and rapid subsidence at the site of Marina Magdalena Rise. The velocity model obtained from the wide-angle profile, RTS-IM01, coincident with the MCS (Figs. 8, 9), shows a thin crust $(\sim 6-7 \mathrm{~km})$ in the TME with a slight progressive thickening underneath the TMI. The MCS profile 

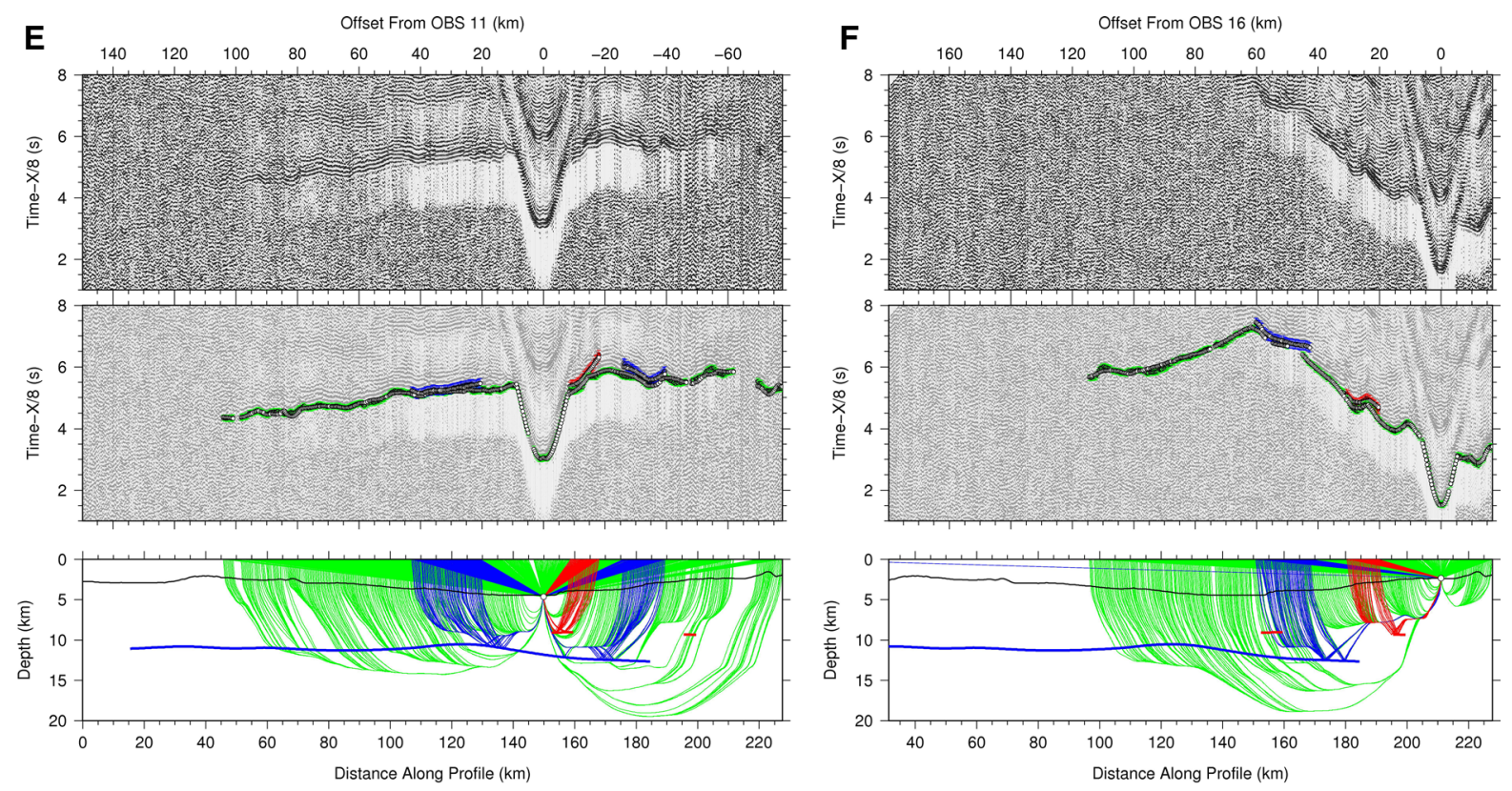

Figure 7 continued

TS13 (Fig. 11), which runs parallel to the TS09b $60 \mathrm{~km}$ southwards, is a short profile $62 \mathrm{~km}$ long ending at the mouth of the strait between Maria Magdalena and Maria Cleofas Islands. The noticeable feature of this profile is that we clearly observe an incipient subducted slab from Rivera Plate with a not yet completely developed accretionary prism, and a narrow trench of $6.0 \mathrm{~km}$, providing a strong indication that the northern subduction of the Rivera Plate stops nearby.

The southern MCS stacked profile, TS11 (Fig. 12) of about $120 \mathrm{~km}$ length shows a complex deformation front, most probably due to the oblique subduction, profile TS11 crosscuts a lineated N-S tectonic structure (named Sierra Cleofas by Nuñez et al. 2016), that can be traced for almost $100 \mathrm{~km}$ in the bathymetry, from south of Marias Islands. This uplifted structure shows a segmented flower-structure consistent with strike slip faulting parallel to the margin. Nuñez et al. (2016) analyze most of the significant structural lineaments in the area, offshore and onshore, and conclude that the main observed trends are NW-SE and N-S. The interplate contact between the Rivera and NA Plates is observed as a strong dipping reflection at $6 \mathrm{~s}$ two-way travel time (TWTT).

Offshore Puerto Vallarta, the MCS data (TS06b) reveals high-amplitude reflections at around 7-8.5 $\mathrm{s}$ TWTT, roughly 2.5-3.5 s TWTT below the seafloor, that conspicuously define the bending morphology of the Rivera Plate at this latitude. These strong reflections have been interpreted as the Moho discontinuity.

The profile that crosses orthogonally all the three above-mentioned MCS profiles, TS08 (Fig. 13), runs parallel to the TMI for a length of $120 \mathrm{~km}$ and crosses the MMR. This seismic section clearly illustrates the bending of the Rivera Plate subducting underneath the Jalisco Block. The wide-angle profile RTS-IM02 is coincident with TS08 MCS section (Fig. 14) and shows a mean crustal thickness for the oceanic domain of less than $10 \mathrm{~km}$, and noticeable low velocity layers immediately underneath the MMR (Figs. 8, 9), coinciding with high heat flow values (Prol-Ledesma et al. 1989). A similar relation between seismic velocities and heat flow values is observed in the mid-ocean ridges (e.g., Lau Basin; Dunn et al. 2013), where both low velocities and 

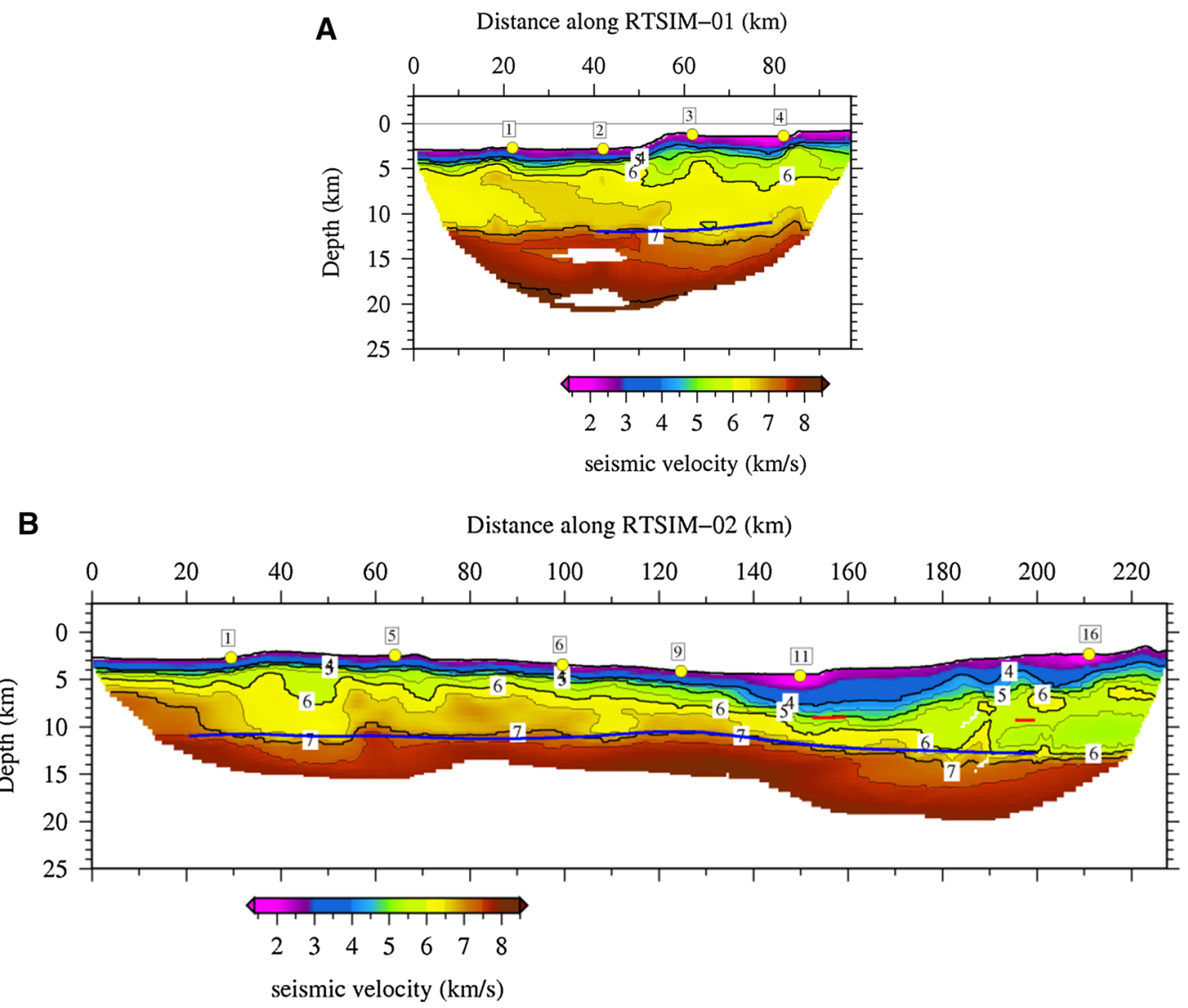

Figure 8

P-wave velocity models for WA profiles RTS-IM01 ( иp) and RTS-IM02 (bottom) obtained inverting the crustal phases identified in the record sections. Numbers at the surface indicate OBSs positions and blue lines show the location of the Moho reflector

thermal anomaly are related to the presence of melt. These anomalous layers, of a mean thickness of $3.0 \mathrm{~km}$ and low seismic velocities with respect to the neighboring crust could have been formed during the overlapping spreading center (OSC) between MMR and EPR $\sim 3.5 \mathrm{Myr}$ ago. The OSC could act as a trap where magma stagnates, which would lead to an increase of the thickness in the extrusive layer and the bulk of the porosity of the upper crust (Bazin et al. 2001) giving a plausible explanation to the anomalous layer geometry. An analogous pattern has been reported beneath overlap relict basins in the EPR (Canales et al. 2003).

\subsection{Bathymetric Features}

The surveyed continental slope westward of Tres Marias islands is characterized by steep slopes that range from about $500 \mathrm{~m}$ water depth to $4164 \mathrm{~m}$ and mean slope gradients of about $12.5^{\circ}$ (Fig. 15). Locally, peaks of more than $25^{\circ}$ are observed between the Maria Magdalena and Maria Cleofas islands presents several arcuate scarps developed in the upper slope and identified as blue lines in Fig. 15b. These structures indicate an area where failures are ubiquitous. The complexity of their headwalls and its relationship suggest a multi-event origin. The continental slope in front of the Maria Magdalena Island presents the biggest landslide scars reaching up to $7.2 \mathrm{~km}$ wide and covering an area of $41.5 \mathrm{~km}^{2}$ (Fig. 15). Downslope, the seafloor are characterized by several lobular surfaces that represent mass-wasting deposits related with upslope scars (colored areas in Fig. 15b). The areal distribution and size of such deposits indicate that the slope off Maria Magdalena Island presents the larger instability 


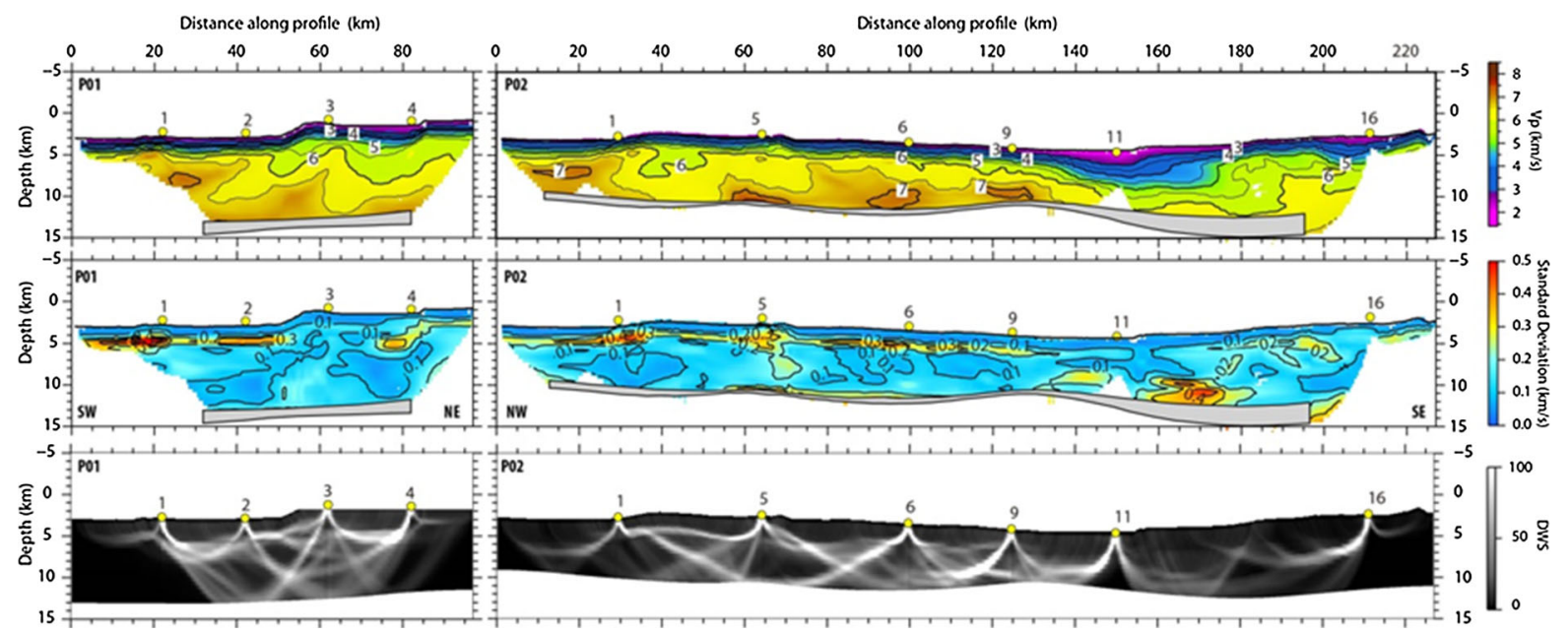

Figure 9

Upper panels show the average of 200 successful Monte Carlo realizations for lines RTS-IM01 (left) and RTS-IM02 (right). Middle panel's show the Vp uncertainty value for each line, whereas the depth uncertainty for the Moho reflector is represented by the grey band in each panel. All the average RMS values for line RTS-IM01 and RTS-IM02 were $64 \mathrm{~ms}\left(\chi^{2} 1.18\right)$ and $57 \mathrm{~ms}\left(\chi^{2} 0.93\right)$, respectively. Lowermost panels show the derivative weight sum (DWS) average of the 200 Monte Carlo realizations that might be taken as a proxy of the ray density through the model

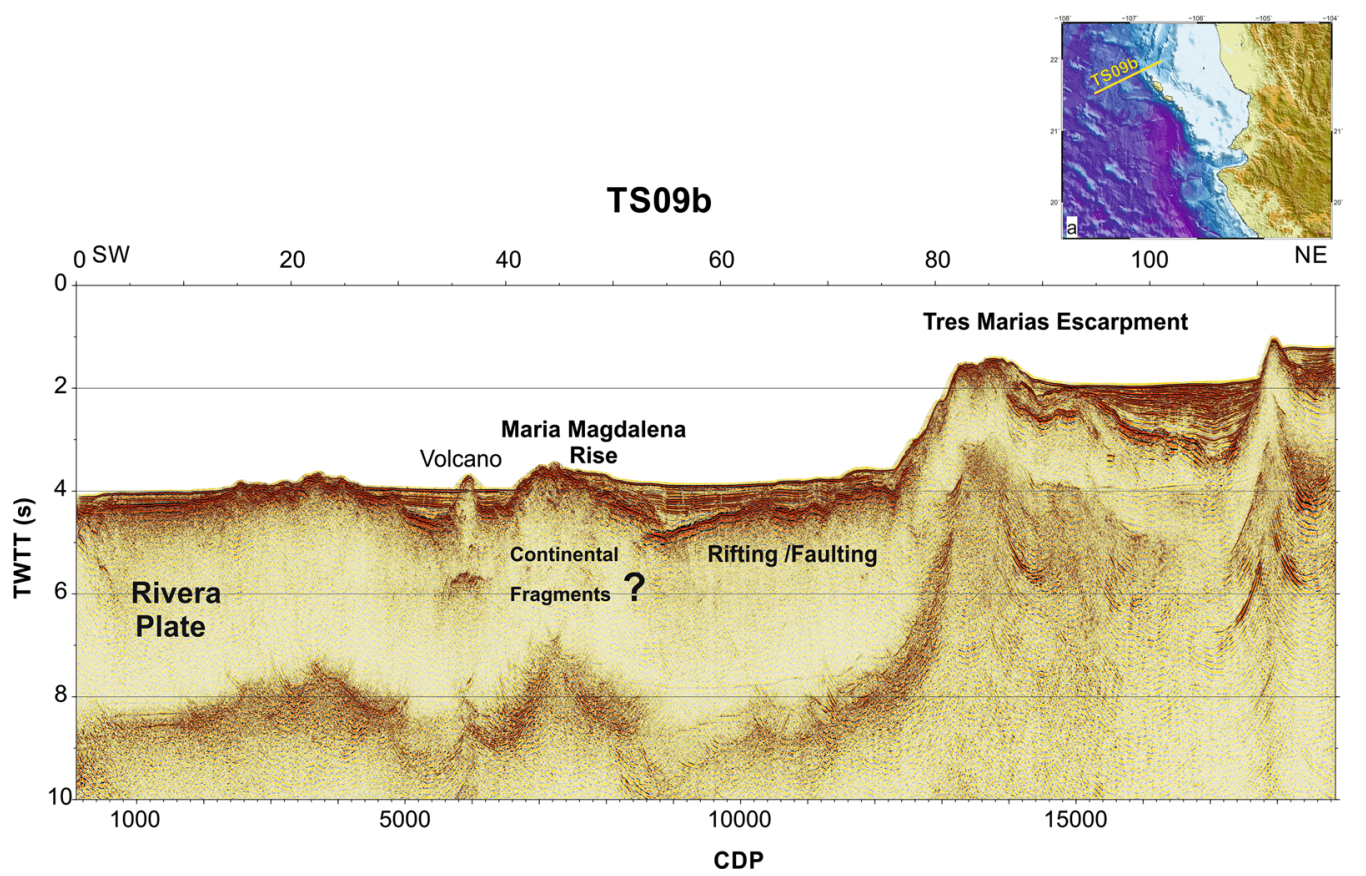

Figure 10

Migrated MCS profile TS09b, striking SW-NW with a length of $120 \mathrm{~km}$. This northern profile shows the absence of subduction north of Tres Marias Islands and the morphology could be the consequence of the extension related to the opening of the Gulf of California 


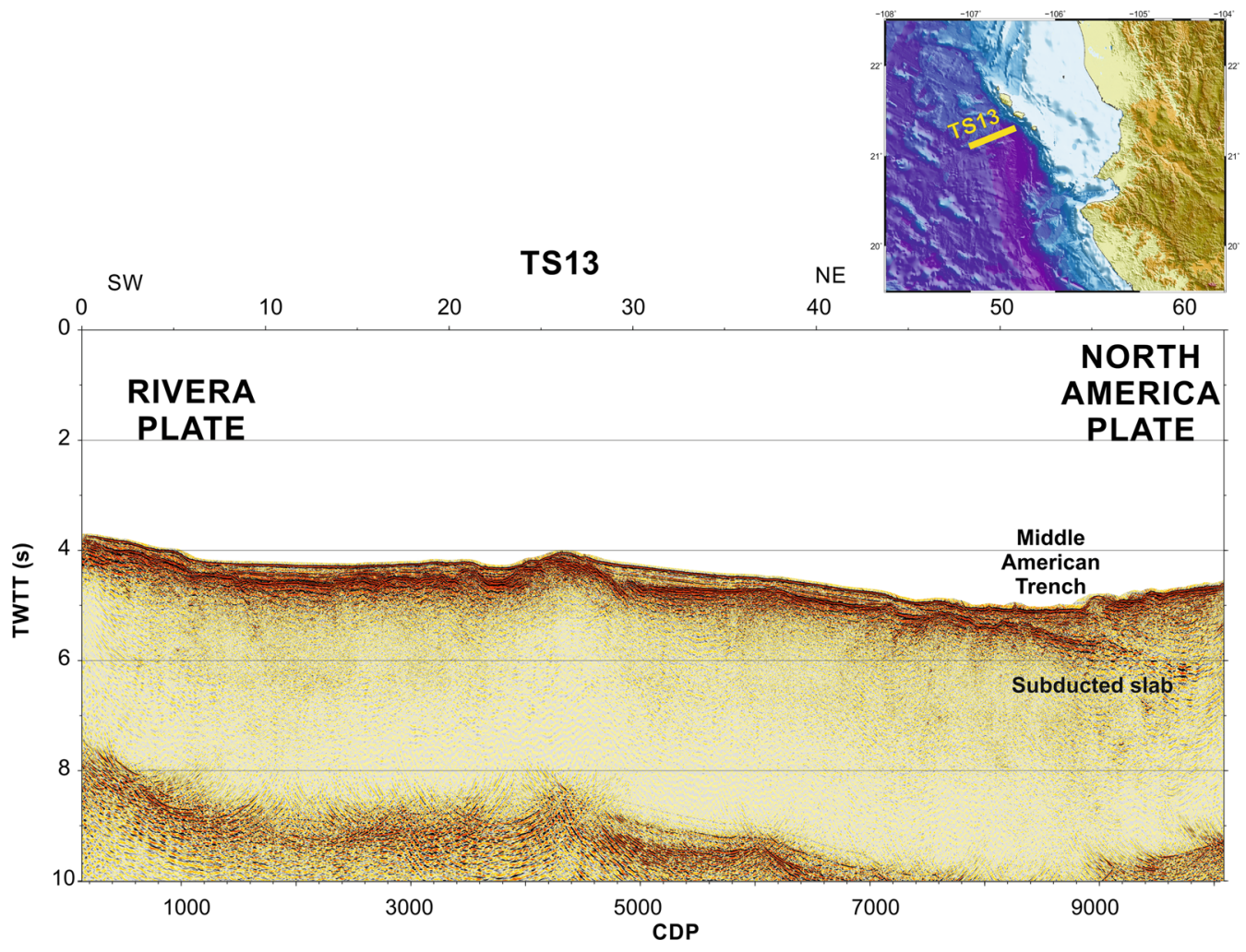

Figure 11

Migrated MCS profile TS13, striking SW-NW with a length of $63 \mathrm{~km}$ showing the presence of subduction between the two southern islands in the Tres Marias area

events. In this sense, and related with the biggest scar, a lobular uneven surface of $112 \mathrm{~km}^{2}$ develops (Fig. 15). Its roughness and dimensions suggest the existence of a huge mass-wasting deposit containing several blocks (the biggest $1.7 \times 0.9 \mathrm{~km}$ ). This configuration resembles debris avalanche deposits identified in volcanic margins (Gee et al. 2001; Chiocci and de Alteriis 2006) or subduction zones (von Huene et al. 2004) where predominate steep gradients and slope instability are inherent.

\section{Conclusions}

Newly acquired seismic data illuminate the complex interactions between Rivera and North American plates, giving insights of the geodynamics at the northern edge of these plates.

We have identified in the MCS sections the collision zone between the Rivera and North American plates in the region of the Tres Marias Islands, which shows noteworthy differences from north to south. North of Tres Marias Islands there is no clear indication of an active subduction zone, instead we observe faulting at the west flank of the Tres Marias Islands, while southwards between Maria Magdalena and Maria Cleofas Islands, we clearly observe the subducted slab of the Rivera Plate with an incipient accretionary prism indicating near termination of the subduction zone. At the southwest edge of the Tres Marias islands the seismic images show unequivocally the Rivera Plate slab subducting underneath Jalisco Block. The subducted Moho is observed at the Rivera Plate, in the southern profile TS11 perpendicular to the North American Plate as a clear bending interface from the outer trench at $8.0 \mathrm{~s}$ (TWTT) to $8.4 \mathrm{~s}$ TWTT underneath the MAT (Fig. 12). The crustal velocity structure and depth of the Moho along RTS-IM01 and RTS-IM02 profiles is significantly well resolved despite the high receiver spacing $(\sim 20 \mathrm{~km})$, as shown 


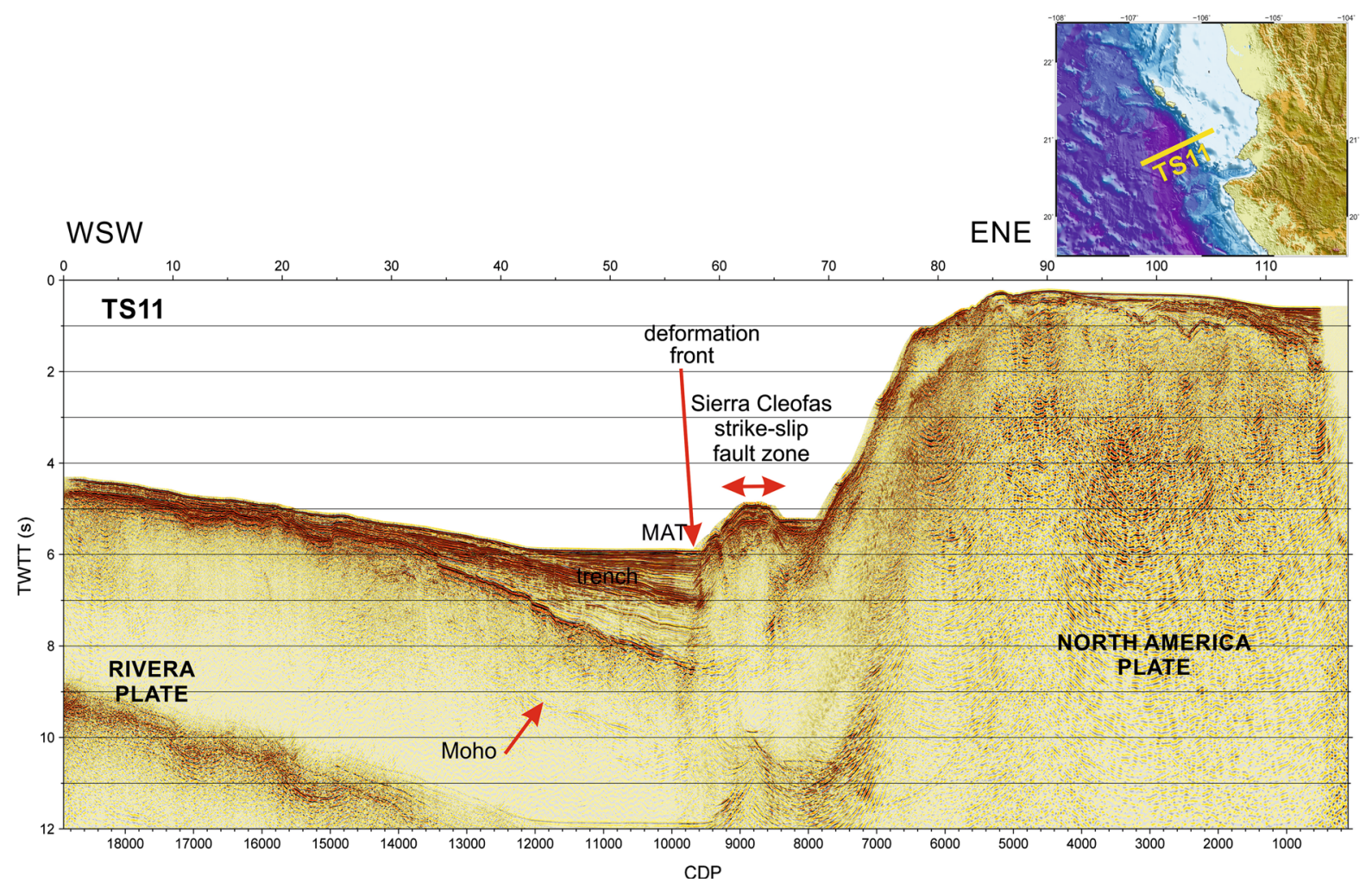

Figure 12

Migrated MCS profile TS11, striking SW-NW with a length of $120 \mathrm{~km}$ showing a clear subduction morphology of the Rivera Plate beneath North America Plate

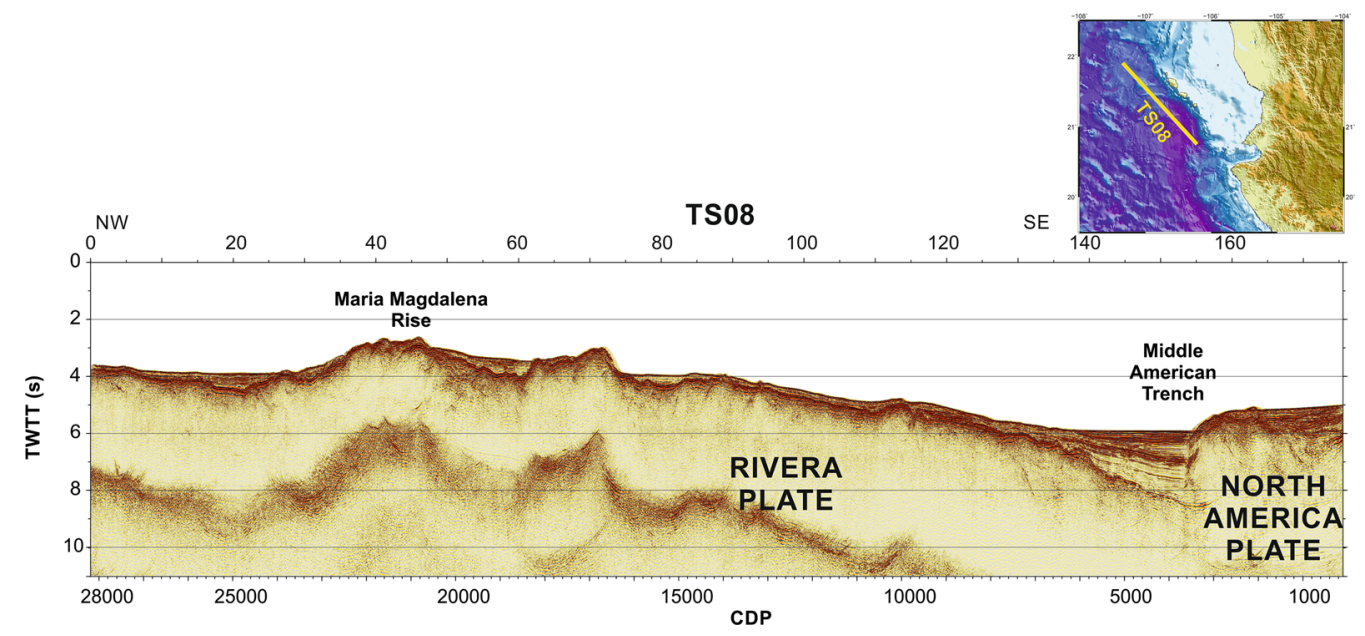

Figure 13

Migrated MCS profile TS08, striking NW-SE with a length of $120 \mathrm{~km}$ and running parallel to the margin 


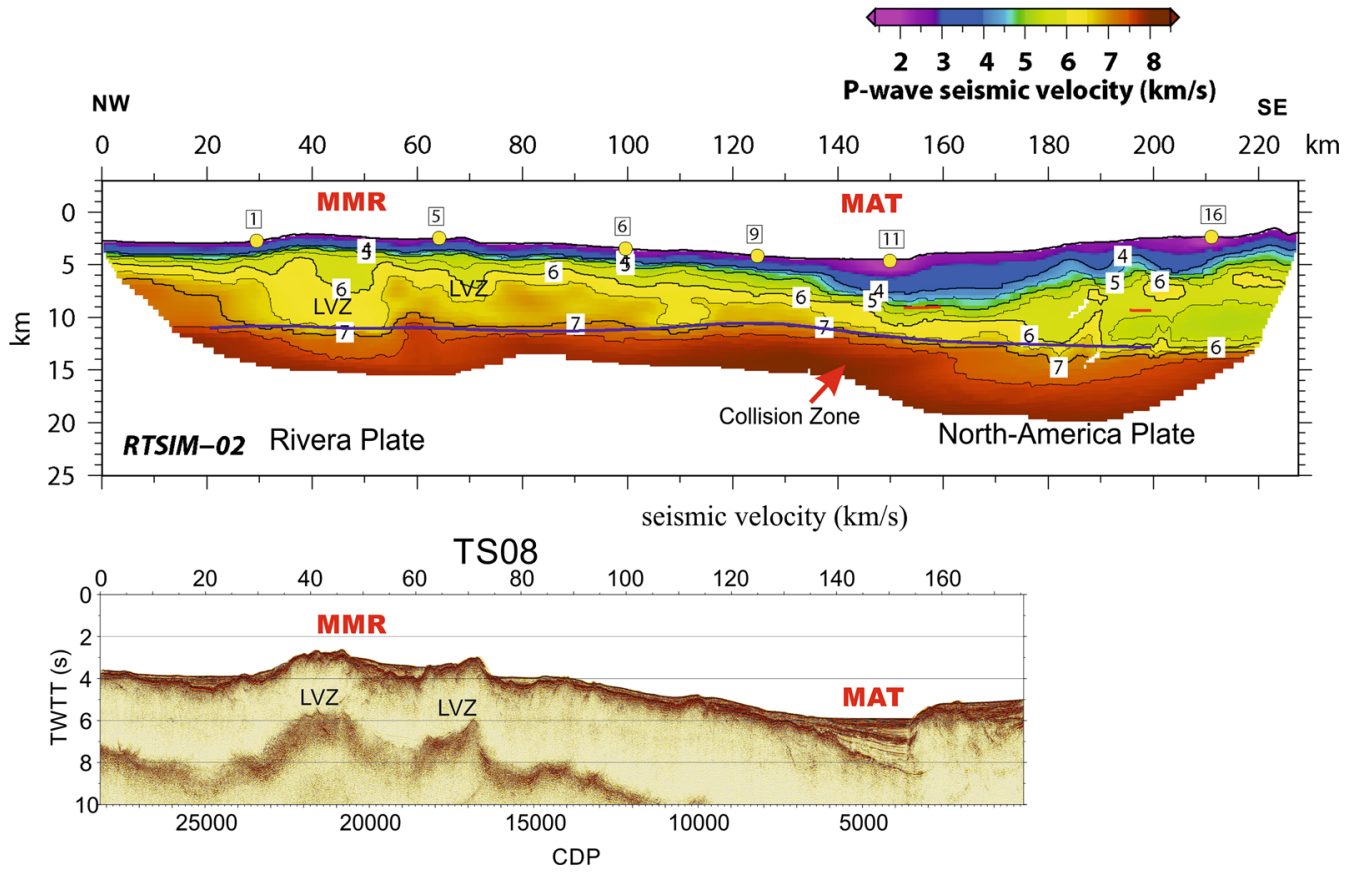

Figure 14

Up panel P-wave velocity model of profile RTS-IM02 from tomographic inversion. Red line shows interplay boundary of Rivera Plate-Jalisco Block (NA Plate), blue lines denote the Rivera oceanic Moho. Down panel shows the coincident MCS profile TS08, located west of Marias Islands, and striking NW-SE with a length of $120 \mathrm{~km}$

in the Monte Carlo analysis. The RMS travel time misfit for the final models (i.e., RTS-IM01 and RTSIM02) is $40 \mathrm{~ms}$ and $50 \mathrm{~ms}$, respectively (Fig. 8). The modeling and interpretation of WA data show a mean crustal thickness for the oceanic slab of 6-7 km, and several relatively low conspicuous crustal velocity variations ( $\$ 5.5 \mathrm{~km} / \mathrm{s}$ ) underneath MMR, that could indicate an excess of melting material feeding from the extinct overlapping spreading center, and a progressive crustal thickening towards the Jalisco Block. While the Moho depth varies from $10 \mathrm{~km}$ westward TMI, to more than $15 \mathrm{~km}$ at the start of collision zone between Rivera Plate and Jalisco Block. Superficial faulting and mass-wasting deposits indicated by the bathymetric data, denotes recent (quaternary) activity west of the TMI. The Tres Marias Escarpment is characterized by steep slopes reaching gradients up to $12.5^{\circ}$, between the Maria Magdalena and Maria Cleofas islands arcuate scarps developed in the upper slope, favoring failures and significant landslides, as the identified landslide, such scars at the foot of Maria Magdalena Island that extends for almost $42 \mathrm{~km}^{2}$, containing blocks up to $2.5 \mathrm{~km}^{2}$. At continental slope margins typically gradients of only $1^{\circ}-5^{\circ}$ can produce large scale failures, so slope instability in the area are certainly favored and possibly triggered by the local seismicity. MB and SBP data show indications of compression, west of Marias Islands, suggested by deformation of sedimentary wedges and elevation of the Islands (Fig. 15).

\section{Acknowledgments}

This research was supported by TSUJAL (Crustal characterization of the Rivera Plate-Jalisco Block boundary and its implications for seismic and tsunami hazard assessment, funded by the Spanish National Agency (Ref. CGL2011-29474-C02-01) and "Ramon y Cajal” program (R. Bartolome). The Government of Jalisco State has also funding for this project with various funds CONACYT-FOMIXJAL 2008-96567 (2009); CON- 848, CONACYT-FOMIXJAL 2008-96539 (2009); 849, CONACYT-FOMIXJAL 

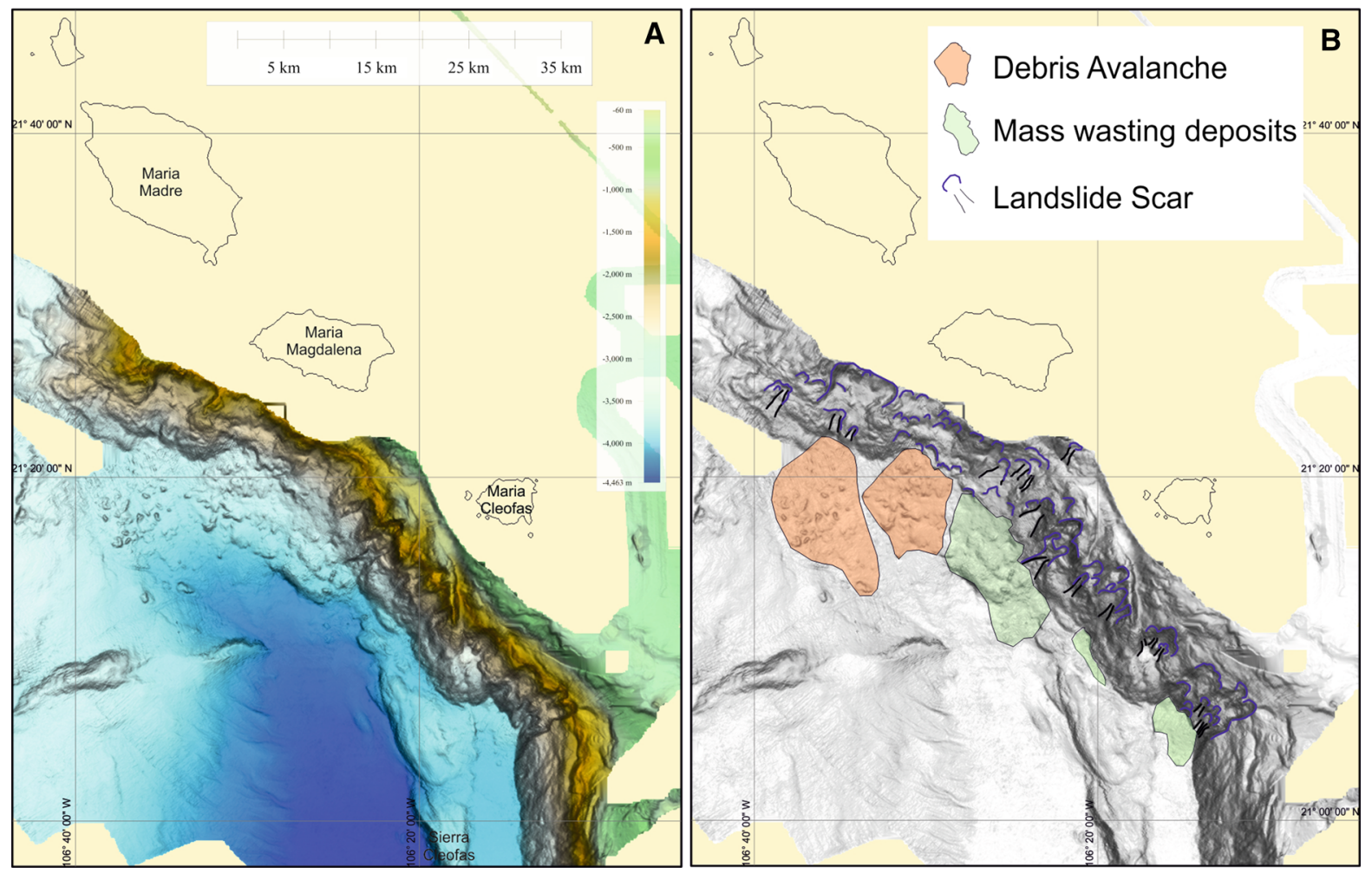

Figure 15

a Multibeam bathymetry of the continental margin westward off Tres Marias Islands. b Shaded relief with geomorphological interpretations showing margin instabilities characterized by landslide scars in the upper slope and mass-wasting deposits at the base of the slope

2010-149245 (2011); 850, CONACyT-FOMIXJal (2012-08-189963) and also 851, partial funding was provided by UNAM DGAPA 852 Grant \#IN1155133 and CABO Project JGAP2013, and UNAM DGAPA Grant \#IN114602.. The Mexican Army provided the vessel ARM HOLZINGER for the environmental assessment and companion vessel for the multichannel seismic acquisition during the survey. We acknowledge the technical staff at UTM-CSIC, NERC, and crew of RSS JAMES COOK, Holzinger and the Mexican SEMAR and the support of the Mexican Instituto Oceanográfico del Pacífico in Manzanillo for their help during the entire cruise.

Open Access This article is distributed under the terms of the Creative Commons Attribution 4.0 International License (http:// creativecommons.org/licenses/by/4.0/), which permits unrestricted use, distribution, and reproduction in any medium, provided you give appropriate credit to the original author(s) and the source, provide a link to the Creative Commons license, and indicate if changes were made.

\section{REFERENCES}

Allan, J. F. (1986). Geology of the Northern Colima and Zacoalco Grabens, southwest Mexico: Late Cenozoic rifting in the Mexican Volcanic Belt. Geological Society of America Bulletin, 97, 473-485.

Allan, J. F., Nelson, S. A., Luhr, J. F., Charmichael, I. S. E., Wopat, M., Wallace, P. J. (1991). Pliocene-Holocene rifting and associated volcanism in southwest Mexico: An exotic terrane in the making. In J. Dauphin \& B. Simoneit (Eds.), The Gulf and Peninsular Provinces of the Californias, AAPG Memoir 47 (pp. 425-445). American Association of Petroleum Geologists: Tulsa.

Alvarez, R., \& Yutsis, V. (2015). The elusive Rivera-Cocos plate boundary: not diffuse. In T. J. Wright, A. Ayele, D. J. Ferguson, T. Kidane, \& C. Vye-Brown (Eds.), Magmatic Rifting and Active Volcanism (vol 420). Geological Society: London.

Atwater, T. M., \& Stock, J. (1998). Pacific-North America plate tectonics of the Neogene south western United States: An update. International Geology Review, 40, 375-402.

Bandy, W.L. (1992). Geological and geophysical investigation of the Rivera Cocos plate boundary: Implications for plate fragmentation, Ph.D. dissertation, Texas A\&M University, College Station, p. 195.

Bandy, W. L., Kostoglodov, V., Hurtado-Díaz, A., \& Mena, M. (1999). Structure of the southern Jalisco subduction zone, 
Mexico, as inferred from gravity and seismicity. Geofisica Internacional, 38, 127-136.

Bandy, W. L., Michaud, F., Bourgois, J., Calmus, T., Dyment, J., Mortera-Gutiérrez, C. A., et al. (2005). Subsidence and strikeslip tectonism of the upper continental slope off Manzanillo, Mexico. Tectonophysics, 398(3-4), 115-140.

Bandy, W. L., \& Mortera, C. A. (2012). Gas hydrates in the southern Jalisco subduction zone as evidenced by bottom simulating reflectors in multichannel seismic reflection data of the 2002 BART/FAMEX campaign. Geofisica Internacional, 51(4), 393-400.

Bandy, W. L., Mortera-Gutierrez, C. A., \& Urrutia-Fucugauchi, J. (1993). Gravity field of the southern Colima graben, Mexico. Geofisica Internacional, 32, 561-567.

Bandy, W., Mortera-Gutierrez, C., Urrutia-Fucugauchi, J., \& Hilde, T. W. C. (1995). The subducted Rivera-Cocos plate boundary: Where is it, what is it, and what is its relationship to the Colima rift? Geophysical Research Letters, 22, 3075-3078.

Bandy, W. L., \& Yan, C. Y. (1989). Present-day Rivera-Pacific and Rivera-Cocos relative plate motions (abstract). EOS. Transactions of the American Geophysical Union, 70, 1342.

Bartolome, R., Dañobeitia, J. J., \& Cordoba, D. (2015). Seismic research in Western Mexico. Sea Technology, 56(10), 25-29.

Bartolome, R., Dañobeitia, J. J., Michaud, F., Córdoba, D., \& Delgado-Argote, L. (2011). Imaging the seismic crustal structure of the western Mexicana margin between $19^{\circ} \mathrm{N}$ and $21^{\circ} \mathrm{N}$. Pure and Applied Geophysics, 168, 1373-1389.

Bartolome, R., Górriz, E., Dañobeitia, J.J, Cordoba, D., Martí, D., Cameselle, A.L., Núñez-Cornú, F., Bandy, W., Mortera, C. A., Castellón, A., Alonso, J.L. (2016). Multichannel seismic imaging of the Rivera Plate subduction at the seismogenic Jalisco Block area (Western Mexican margin). Pure and Applied Geophysics (this volume) (in press).

Bazin, S., Harding, A. J., Kent, G. M., Orcutt, J. A., Tong, C. H., Pye, J. W., et al. (2001). Three-dimensional shallow crustal emplacement at the at the $9^{\circ} 30^{\prime} \mathrm{N}$ overlapping spreading center on the East Pacific Rise: Correlations between and tomographic images. Journal Geophysical Research, 106, 16101-16117. doi:10.1029/2002GL015137.

Bourgois, J., \& Michaud, F. (1991). Active fragmentation of the North American plate at the Mexicana triple junction area off Manzanillo (Mexico). Geo-Marine Letters, 11, 59-65.

Bourgois, J., Renard, D., Auboin, J., Bandy, W., Barrier, E., Calmus, T., et al. (1988). Fragmentation en cours du bord Ouest du Continent Nord Americain: Les frontieres sous-marines du Bloc Jalisco (Mexique). Comptes rendus de l'Académie des sciences, Paris, 307(II), 1121-1133.

Canales, J. P., Detrick, R. S., Toomey, D. R., \& Wilcok, W. S. D. (2003). Segment-scale variations in the crustal structure of 150-300 kyr old fast spreading oceanic crust (East Pacific Rise, $8^{\circ} 15^{\prime} \mathrm{N}-10^{\circ} 5^{\prime} \mathrm{N}$ ) from wide-angle seismic refraction profiles. Geophysical Journal International, 152, 766-794. doi:10.1046/j. 1365-246X.2003.01885.x.

Chiocci, F. L., \& de Alteriis, G. (2006). The Ischia debris avalanche: first clear submarine evidence in the Mediterranean of a volcanic island prehistorical collapse. Terra Nova, 18(3), 202-209.

Courboulex, F., Singh, S. K., Pacheco, J. F., \& Ammon, C. J. (1997). The 1995 Colima-Jalisco, Mexico, Earthquake $\left(M_{\mathrm{w}} 8\right)$ : A study of the rupture process. Geophysical Reseach Letters, 24, 1019-1022. doi:10.1029/97GL00945.
Dañobeitia, J. J., Córdoba, D., Delgado-Argote, L. A., Michaud, F., Bartolomé, R., Farrán, M., et al. (1997). Expedition gathers new data on crust beneath Mexicana West Coast. Eos, Transactions American Geophysical Union, 78(49), 565-572.

DeMets, C., \& Stein, S. (1990). Present-day kinematics of the Rivera Plate and implications for tectonics in Southwestern Mexico. Journal Geophysical Research, 95(B13), 21931-21948.

DeMets, C., \& Traylen, S. (2000). Motion of the Rivera plate since 10 Ma relative to the Pacific and North American plates and the mantle. Tectonophysics, 318, 119-159.

Dunn, R. A., Martinez, F., \& Conder, J. A. (2013). Crustal construction and magma chamber properties along the Eastern Lau Spreading Center. Earth and Planetary Science Letters, 371-372, 112-124.

Eissler, H. K., \& McNally, K. C. (1984). Seismicity and tectonics of the Rivera Plate and implications for the 1932 Jalisco, Mexico, earthquake. Journal Geophysical Research, 89, 4520-4530.

Ferrari, L., Petrone, C., \& Francalanci, L. (2001). Generation of oceanic-island basalt-type volcanism in the western TransMexican volcanic belt by slab rollback, asthenosphere infiltration, and variable flux melting. Geology, 29, 507-510.

Gee, M. J. R., Watts, A. B., Masson, D. G., \& Mitchell, N. C. (2001). Landslides and the evolution of El Hierro in the Canary Islands. Marine Geology, 177, 271-293.

Gutierrez, Q. J., Escudero, C. R., Núñez-Cornú, F. J. (2015). Geometry of the Rivera-Cocos subduction zone inferred from local seismicity. Bulletin of the Seismological Society of America, 105(6), 3104-3113. doi: 10.1785/012010358. (ISSN: 0037-1106)

Jaramillo, S. H., \& Suarez, G. (2011). The 4 December 1948 earthquake $\left(M_{\mathrm{w}} 6.4\right)$ : Evidence of reverse faulting Beneath the Tres Marías escarpment and its implications for the Rivera-North American relative plate motion. Geofísica Internacional, 50(3), 313-317.

Johnson, C. A., Harrison, C. G. A. (1989). Tectonics and volcanism in central Mexico: A Landsat Thematic Mapper perspective. Remote Sensing of Environment, 28, 273-286.

Khutorskoy, M. D., Delgado-Argote, L. A., Fernandez, R., Kononov, V. I., \& Polyak, B. G. (1994). Tectonics of the offshore Manzanillo and Tecpan Basins, Mexican Pacific, from heat flow, bathymetric and seismic data. Geofisica Internacional, 33(1), 161-185.

Klitgord, K. D., \& Mammerickx, J. (1982). Northern east Pacific rise: Magnetic anomaly and bathymetric framework. Journal Geophysical Research, 87, 6725-6750. doi:10.1029/JB087iB08p06725.

Korenaga, J., Holbrook, W. S., Kent, G. M., Kelemen, P. B., Detrick, R. S., Larsen, H. C., et al. (2000). Crustal structure of the southeast Greenland margin from joint refraction and reflection seismic tomography. Journal of Geophysical Research, 105(B9), 21591-21614. doi:10.1029/2000JB900188.

Korenaga, J., \& Sager, W. W. (2012). Seismic tomography of Shatsky rise by adaptive importance sampling. Journal Geophysical Research, 117, B0812. doi:10.1029/2012JB009248.

Kostoglodov, V., \& Bandy, W. (1995). Seismotectonic constraints on the convergence rate between the Rivera and North American plates. Journal Geophysical Research, 100, 17977-17989. doi:10.1029/95JB01484.

Lonsdale, P. (1991). Structural patterns of the Pacific floor offshore of Peninsular California. In: J.P. Dauphin, B.R.T. Simoneit (Eds.), AAPG Memoir: The Gulf and Peninsular Province of the Californias. Am. Assoc. Petr. Geol., Tulsa. 47: 87-125.

Mammerickx, J. (1984). The Morphology of propagating spreading centers: New and old. Journal Geophysical Research, 89, 1817-1828. 
Mammerickx, J., \& Kiltgord, K. (1982). Northern East Pacific Rise: Evolution from 25 my B.P to the present. Journal Geophysical Research, 87, 6751-6759.

McCloy, C., Ingle, J. C., Barron, J. A. (1988). Neogene stratigraphy, foraminifera, diatoms, and depositional history of María Madre Island Mexico: Evidence of Early Neogene marine conditions in the southern Gulf of California. Marine Micropaleontology, 13, 193-212.

Mercier de Lépinay, B., Michaud, F., Calmus, T., Bourgois, J., Poupeau, G., Saint-Marc, P., The Nautimate Team (1997). Large Neogene subsidence event along the Middle America Trench off Mexico $\left(18^{\circ}-19^{\circ} \mathrm{N}\right)$ : Evidence from submersible observations. Geology, 25, 387-390.

Michaud, M., Dañobeitia, J. J., Carbonell, R., Bartolomé, R., Córdoba, D., Delgado, L., et al. (2001). New insights into the subducting oceanic crust in the Middle American Trench off western Mexico (17-19 N). Tectonophysics, 318(1), 187-200.

Michaud, F., Royer, J.-Y., Bourgois, J., \& Mercier de Lepinay, B. (1996). Comment on "Segmentation and disruption of the East Pacific rise in the Mouth of the Gulf of California" by Peter Lonsdale (Marine Geophysical Researches 17, pp. 323-359, 1995). Marine Geophysical Researches, 18, 597-599.

Minshull, T., Bartolomé, R., Byrne, S., \& Dañobeitia, J. J. (2005). Low heat flow from young oceanic lithosphere at the Middle America Trench off Mexico. Earth and Planetary Science Letters, 239, 33-41. doi:10.1016/j.eps1.2005.05.045.

Moore, D. G., \& Curray, J. R. (1982). Geologic and tectonic history of the Gulf of California. Initial Reports of the Deep Sea Drilling Project, 64, 1279-1294.

Nixon, G. T. (1982). The relationship between Quaternary volcanism in central Mexico and the seismicity and structure of subducted ocean lithosphere. Geological Society of America Bulletin, 93, 514-523.

Núñez-Cornú, F. J. (2011). Peligro Sísmico en el Bloque de Jalisco. Física de la Tierra, 23, 199-229. doi:10.5209/rev_FITE.2011. v23.36919.

Núñez-Cornú, F. J., Córdoba Barba, D., Dañobeitia, J. J., Bandy, W. L., Ortiz, M., Bartolome, R., et al. (2016). Geophysical studies across Rivera Plate and Jalisco Block, MEXICO: TsuJal project. Seismological Research Letters, 87(1), 59-72. doi:10. 1785/0220150144.

Núñez-Cornú, F. J., Reyes-Dávila, G. A., Rutz López, M., TrejoGómez, R., Camarena-Garcia, M. A., \& Ramírez-Vazquez, C. A. (2004). The 2003 Armería, México earthquake ( $M_{\mathrm{w}}$ 7.4): Mainshock and early aftershocks. Seismological Research Letters, 75(6), 506-605.

Nuñez-Cornú, F., Rutz, M., Nava, F. A., Reyes-Davila, G., \& Suarez-Plascencia, C. (2002). Characteristics of the seismicity in the coast and north of Jalisco Block, Mexico. Physics of the Earth and Planetary Interiors, 132, 141-155.

Okal, E. A., \& Borrero, J. C. (2011). The 'tsunami earthquake' of 22 June 1932 in Manzanillo, Mexico: seismological study and tsunami simulations. Geophysical Journal International, 187, 1443-1459.
Pacheco, J., Singh, S. K., Domínguez, J., Hurtado, A., Quintanar, L., Jiménez, Z., et al. (1997). The October 9, 1995 ColimaJalisco, Mexico earthquake $\left(M_{\mathrm{w}} 8\right)$ : an aftrshock study and a comparison of this earthquake with those of 1932. Geophysical Research Letters, 24(17), 2223-2226.

Pardo, M., Suárez, G. (1995). Shape of the subducted Rivera and Cocos plates in southern Mexico: Seismic and tectonic implications. Journal of Geophysical Research. 100, 12357-12373.

Peláez Gaviria, J. R., Mortera Gutiérrez, C. A., Bandy, W. L., \& Michaud, F. (2013). Morphology and magnetic survey of the Rivera-Cocos plate boundary off Colima, Mexico. Geofisica Internacional, 52, 73-85.

Prol-Ledesma, R.M., Sugrobov, V.M., Flores E.L. Juárez M.G., Smirnov, Y., Gorshkov, A.P., Bondarenko, V.G., Rashidov, V.A., Nedopekin, L.N., Gavrilov, V.A. (1989). Component parts of the World Heat Flow Data Collection. doi:10.1594/ PANGAEA.805577.

Sallarès, V., Martinez-Loriente, S., Prada, M., Gràcia, E., Ranero, C., Gutscher, M. A., et al. (2013a). Seismic evidence of exhumed mantle rock basement at the Gorringe Bank and the adjacent Horseshoe and Tagus abyssal plains (SW Iberia). Earth and Planetary Science Letters, 365, 120-131. doi:10.1016/j.epsl. 2013.01.021.

Sallarès, V., Meléndez, A., Prada, M., Ranero, C. R., McIntosh, K., \& Grevemeyer, I. (2013b). Overriding plate of the Nicaragua convergent margin: Relationship to the seismogenic zone of the 1992 tsunami earthquake. Geochemistry Geophysics Geosystems, . doi:10.1002/ggge20214.

Selvans, M., Stock, J., DeMets, C., Sanchez, O., \& Marquez-Azua, B. (2011). Constraints on Jalisco Block motion and tectonics of the Guadalajara triple junction from 1998-2001 Campaign GPS Data. Pure and Applied Geophysics, . doi:10.1007/s00024-010-0201-2.

Singh, S. K., Ponce, L., \& Nishenko, S. (1985). The great jalisco, Mexico earthquake of 1932: subduction of the Rivera plate. Bulletin of the Seismological Society of America, 75, 1301-1313.

Tarantola, A. (1987). Inverse problem theory: methods for data fitting and model parameter estimation. New York: Elsevier Sci.

Toomey, D. R., \& Foulger, G. R. (1989). Tomographic inversion of local earthquake data from the Hengill-Grensdalur central volcano complex, Iceland. Journal of Geophysical Research, 94, 17497-17510.

Trejo-Gómez, E., Ortíz, M., \& Núñez-Cornú, F. J. (2015). Source Model of the October 9, 1995 Jalisco-Colima Tsunami as constrained by field re survey reports, and on the numerical simulation of the tsunami. Geofísica Internacional, 54(2), 149-159.

von Huene, R., Ranero, C. R., \& Watts, P. (2004). Tsunamigenic slope failure along the Middle America Trench in two tectonic settings. Marine Geology, 203, 303-317.

Yang, T., Grand, S. P., Wilson, D., Guzmán-Speziale, M., GómezGonzález, J. M., Domínguez-Reyes, T., et al. (2009). Seismic structure beneath the Rivera subduction zone from finite-frequency seismic tomography. Journal Geophysical Research, 114, B01302. doi:10.1029/2008JB005830. 